\title{
Strategic transformations in large Irish-owned businesses
}

\section{Colm O'Gorman*}

Dublin City University Business School, Dublin 9, Ireland.

Tel: +35317006941

Colm.OGorman@DCU.ie

\section{Declan Curran}

Dublin City University Business School, Dublin 9, Ireland.

Tel: +35317005798

Declan.Curran@DCU.ie

* Corresponding author

\begin{abstract}
This research explores resistance to a universal business organisation by analysing large firms in Ireland. Drawing on our dataset of large Irish firms, an SSOP informed study identifies strategic transformations such as increased internationalisation and changes in ownership regime across three benchmark years of 1978, 1990 and 2010. However large Irish firms are not characterised by convergence to a universal business organisation. This study contributes to the SSOP project by extending it to a new geographic context and, by including sector of activity, by providing a contextually sensitive explanation for the absence of a universally applicable business organisation.
\end{abstract}

Key words: Strategy-Structure-Ownership-Performance; SSOP; Ireland; Strategy; Ownership; Internationalisation. 


\section{Introduction}

Chandler's seminal research on the evolution of large firms contended that success in large US firms was associated with strategies of related product diversification and expansion into international markets, the adoption of a multi-divisional organisational structure, and increased dispersed ownership regimes. ${ }^{1}$ Critiques of Chandler's studies of business organisation argue that his research does not provide a universally applicable form of business organisation because his studies are 'without geography' ${ }^{2}$ and 'timeless'. ${ }^{3}$ While a stream of subsequent studies has sought to build on Chandler's work, including studies that extend Chandler's strategy-structureownership-performance (SSOP) framework into new territories and that incorporate new dimensions, such as internationalisation, the universal applicability of converging forms of business organisation in large businesses has been questioned by a number of distinct lines of research.

First, empirical studies that extend Chandler's research have challenged the validity of a universally applicable business organisation in diverse and dynamic business contexts, including new territories and more recent time periods. ${ }^{4}$ Drawing on the SSOP framework, Wittington and Mayer argue that large firms in European countries have been characterised by patterns of evolution that differ from those observed by Chandler. ${ }^{5}$ More specifically, recent research that extended the SSOP framework into new contexts reported that large firms in small European countries are characterised by divergent patterns of strategic transformation. For example, Iversen and Larsson find that in Denmark and Sweden a strategy of specialisation in a core business and international expansion have become more important. ${ }^{6}$ The decreased importance of diversification noticed in Sweden from 1993 onwards reflects patterns observed in other European countries such as France, Germany, and the UK. ${ }^{7}$ Similarly, empirical studies have found that publically owned Dutch firms have become larger and more international. ${ }^{8}$ A pattern of development of a specialised business strategy, with growth occurring through geographical expansion, is consistent with the business strategy literature. ${ }^{9}$ However, despite higher levels of international activity, a number of the largest twenty five businesses in both Denmark and Sweden continued to be characterised by a domestic orientation. ${ }^{10}$

Similarly, SSOP studies point to divergent forms of ownership regimes. Whittington \& Mayer found that the patterns of ownership observed in the US are not observed in France and Germany, where family ownership has endured as an important form of ownership in large firms. ${ }^{11}$ A similar pattern of family ownership is observed by Binda in her study of large firms in Spain and Italy. ${ }^{12}$ Whittington and Mayer show that there has been resistance to the multi-divisional organisational structure in France, Germany and the UK, ${ }^{13}$ though this structure was adopted by more large firms in the UK in the 1980s and 1990s. ${ }^{14}$

Second, the common growth paths observed and described by Chandler may not be applicable in new sectors that have emerged in more recent time periods. An important element of Chandler's explanation in Strategy \& Structure was that the common growth paths observed in large firms included growth in new sectors- what he referred to as sectors in the second industrial age. These sectors typically required large capital investments. Technological innovations, specifically ICT innovations, have allowed some firms to benefit from first mover advantage in networked business models and to grow rapidly. ${ }^{15}$ Firm-level research that focusses on the sources of competitive advantage argues that in emerging sectors firms can grow large by pursuing narrow product-market strategies. ${ }^{16}$ 
Third, alternative theoretical explanations such as institutional theory and population ecology offer different explanations for the emergence of large business organisations, and variations in national institutions and culture have resulted in country-based heterogeneity in factors such as types of ownership and sector specialization. ${ }^{17}$ Critiques of Chandler's work include arguments that he prioritised the manager's pursuit of efficiency, resulting in specific business organisation, rather than alternative explanations of managerial actions, such as pursuit of market control. ${ }^{18}$

The critiques of Chandler's work and the findings from the SSOP research in new contexts and new time periods challenge the positivist universalism associated with Chandler's argument that the large, diversified and professional managed organization is best placed to exploit scale and scope economies. ${ }^{19}$ The aim of this research is to explore the continued resistance to converging business organisation by analyzing the strategic transformations in large firms in Ireland. The nature of the strategic transformations of large Irish-owned manufacturing and service firms since Ireland's accession to the EEC in 1973 is analysed in terms of changes in ownership regimes, strategy and internationalisation. The strategic transformations identified in the data are discussed in terms of the sectors of activity of large Irish firms and the churn in firms over the three benchmark years. This approach is in keeping with Whittington's recent suggestion that the SSOP project could develop in three directions: dimensional, territorial and theoretical, ${ }^{20}$ though in extending the SSOP project Whittington and Mayer have argued that research which explores business organization requires an 'increased contextual sensitivity' ${ }^{21}$ and should be informed by contextual relativism rather than positivist universalism. ${ }^{22}$

The remainder of the paper is organised as follows. The next section briefly outlines key aspects of industrial development in Ireland. This is followed by an explanation of how data was gathered and how the dataset of large firms was developed. This is followed by an application of the SSOP framework in an Irish context, focussing on an analysis of the strategic characteristics of the fifty largest Irish-owned firms in each of three benchmark years, 1978, 1990 and 2010, and a comparison of findings for 2010 with those from other European countries. The subsequent section discusses the strategic transformations identified in large Irish firms in terms of (i) sector of activity, and (ii) churn in the firms listed among the fifty largest Irish firms for each of the three benchmark years. To illustrate patterns of transformation we then present short cases studies of four firms that are included in the 2010 dataset. The paper concludes with a discussion of the implications that the lack of convergence of business organisation identified in large Irish firms has for the SSOP research project.

\section{The Irish context}

The strategic transformations of large Irish firms during the period 1978 to 2010 have taken place in the broader context of Irish industrial developments since independence in the 1920s. While mainstream economic characterisations of Irish industrial development since independence tend to be framed in terms of generalised economic theories, the importance of historical context in understanding Irish industrial development process has also been emphasised. ${ }^{23}$ Ireland's industrialisation reflects a series of interlinked structural changes, set against the backdrop of two specific transition phases: the protectionist policy environment of the 1930s to 1950s, and the subsequent trade liberalisation from the 1960s onwards, including Ireland's accession to the European Economic Community (EEC) in 1973. Both the opportunities arising from integration into global markets and challenges posed from exposure to international competition, as well as 
the influence of the neoliberal economic outlook prevailing internationally in the 1980 s, have been well documented in the Irish and European context. ${ }^{24}$

At the time of Ireland's accession to the EEC in 1973, Ireland's income per capita was in the region of $60 \%$ of the European average. However over the period from 1973 to 2010 Ireland experienced rapid convergence to average EU levels and by 2010 Irish Gross National Income (GNI) per capita had surpassed the EU average and stood at $106 \%$ of the European average. ${ }^{25}$ The Irish economy's transition to a predominantly service- and manufacturing- based industry structure gained momentum over this time: service sector value added increased from $48 \%$ to $70 \%$ of total value added over the 1970-2010 period, while the manufacturing and agriculture equivalents fell from $36 \%$ to $28 \%$ and $17 \%$ to $2 \%$ respectively (Figure 1). An important contributing factor to this industrial shift has been the significant inflow of foreign direct investment, attributable in no small measure to a favourable corporation tax regime and a pro-active Industrial Development Authority. ${ }^{26}$ By 2012 non-Irish firms had come to account for $80 \%$ of total Irish manufacturing gross output, while in the services subsector of information and communications non-Irish firms were generating $88 \%$ of total turnover. ${ }^{27}$ Irish policy initiatives such as fiscal stabilisation in the late 1980s, wage moderation via social partnership agreements, and eventual gains accrued from earlier education and infrastructure investment all helped to pave the way for what both Kennedy and Bielenberg and Ryan refer to as Ireland's "late industrialisation". ${ }^{28}$

Despite large investments by the state in industrial development, structural problems persisted within indigenous Irish industry into the 1990s, with issues identified including low levels of profitability, an over-dependence on the domestic and UK markets, commodity products that compete on price, low levels of innovation, low levels of productivity and a concentration in traditional rather than modern sectors. ${ }^{29}$ For example, the historian Joe Lee argued in 1989 that from a historical perspective 'it is difficult to avoid the conclusion that Irish economic performance has been the least impressive in Western Europe, perhaps all of Europe, in the twentieth century'. ${ }^{30}$ Kennedy notes the inability of indigenous manufacturers to penetrate global export markets by the late 1980s, pointing out that excluding resource-based food processing firms, only a small number of Irish firms had made the transition to large-scale specialised businesses by that time, and that rather than using the export route, they set up or acquired subsidiary operations in host countries. ${ }^{31}$ Ó Gráda neatly captures the efforts of indigenous manufacturers to adapt to the intense competition ushered in by trade liberalisation: "survival thus might involve a range of strategies: surrendering managerial control, swapping production for agency, focusing on niche products, exporting entrepreneurial skill through investing abroad". ${ }^{32}$ Recognising these problems, both the Telesis Report (1982) and the Culliton report (1992) both called for greater policy emphasis on indigenous industry. ${ }^{33}$

Although eclipsed to a large extent by the phenomenal performance of foreign-owned firms throughout the 1990s and into the early 2000s, indigenous Irish firm experienced something of a revival during this "Celtic Tiger" period. ${ }^{34}$ Ó Riain points to discernible increases in output, employment, R\&D, and productivity throughout the 1990s among Irish-owned firms active in the electronics, instruments, and software sectors, though the performance of firms engaged in traditional manufacturing and sub-supply experienced only modest growth. ${ }^{35}$

However, the sustainability of this indigenous growth has subsequently been questioned. Roper et al. note that Irish indigenous exports experienced slower growth over the 1991-1998 period than over previous 1986-1991 period. ${ }^{36}$ Forfás, the national policy advisory board for science and technology, speculated that this weak export performance may have been due to indigenous firms being acquired by foreign investors, as well as indigenous firms switching their 
focus from export markets to a growing domestic market. ${ }^{37}$ The 2004 O'Driscoll report also highlighted the perceived poor export performance of Irish owned firms, stating 'over the period 1990-2002, exports by agency-assisted indigenous enterprise grew in nominal terms at 5.5\% per annum (versus $15.9 \%$ for foreign-owned companies); when inflation is taken into account, the real growth in both sales and exports was negligible'. ${ }^{38}$ Over the period 2000-2008, indigenous exports continued to grow in nominal terms at $5 \%$ per annum on average, and after a downturn in 20092010, grew by $8 \%$ in 2011. ${ }^{39}$ Along with this growth, albeit modest, of indigenous exports, indigenous foreign direct investment outflows also grew from the 1990s into the 2000s; according to the CSO, in 2012 direct investment abroad, excluding financial and insurance activities, stood at $€ 113.7$ billion, in comparison to non-IFSC (International Financial Service Centre) direct investment abroad of $€ 17.3$ billion in 1998 . $^{40}$

Barry et al. note that this outward FDI pattern adheres to the Investment Development Path hypothesis developed by Dunning (1981, 1986), which posits a U-shaped relationship between economic development and a country's net investment position. However, Barry et al. find that by the early 2000s Irish outward FDI was disproportionately horizontal in nature and flowed predominantly into low technology non-traded sectors such as construction materials and paper and packaging. ${ }^{41}$ This orientation towards low technology outward investment is also apparent in 2012 CSO data, with the food, beverages and tobacco products sub-sector accounting for $34 \%$ of total manufacturing direct investment abroad, while in the services sector, the stock of outward investment in wholesale and retail ( $€ 13.4$ billion) was more than double that of outward investment in information and communication activities (€6 billion). ${ }^{42}$ As with export performance, Irish foreign investment outflows indicate that while indigenous firms have become more internationalized, they have done so predominantly in low technology activities.

\section{Insert Figure 1: \\ Value added by activity, as a percentage of total value added, 1970-2010 ${ }^{43}$}

\section{Sample selection, sources, and definitions}

The aim of this research is to explore the continued resistance to converging business organisation by analyzing the strategic transformations in large firms in Ireland. This study analyses the 50 largest indigenous Irish firms for three benchmark years, 1978, 1990 and 2010 with reference to (i) the strategic dimensions of the SSOP framework: strategy, internationalisation, and ownership, ${ }^{44}$ and (ii) the sectors of activity in terms of NACE and Eurostat classifications, and Peneder's two classifications of manufacturing industry. ${ }^{45}$ These three years were chosen to provide an insight into modern Ireland's industrial development as prior research by O'Malley has argued that the period of development up to the mid-1980s was characterised by a restructuring of the Irish economy, with many traditional sectors declining as the economy became more open. ${ }^{46}$ As such, the 1978 time period provides an insight into Ireland's largest firms at a time when the Irish economy was adjusting to the emerging economic integration, while the later time periods provide insight into the firms that remained large and the new firms that emerged as large firms. The choice of 1978 as starting year for our analysis reflects data availability, as described below.

This study follows the definitions and adaptations used in the Mapping Corporate Europe project, as drawn from the SSOP framework developed by Whittington and Mayer. ${ }^{47}$ To classify the sector, strategy, internationalisation, and ownership of these firms we draw on a number of data sources. We used the FAME database, which is based on official company annual returns to 
the Irish Companies Registration Office. Where necessary we used the original submission to the Companies Registration Office in Dublin. We used company annual reports accessed through library holdings (The National Library, University College Dublin and Trinity College Dublin), and online published annual reports. For the co-operatives (an important ownership structure in the 1978 data) we used annual reports held in the Centre for Cooperative Studies, University College Cork. We also used newspaper reports, drawn principally from the Irish Times Archive (a leading Irish Newspaper), and from the Irish Newspaper Archive (an archive of both regional and national Irish newspapers).

\section{Sample: identifying the largest fifty firms in Ireland}

In creating a list of the largest fifty firms for each time period, we used contemporaneous published lists that were compiled from annual reports and company filing data (See Table A1 in Appendix 1 for a listing of the firms for each of the three benchmark years). The primary source used was an annual list published since 1979 by the business magazine, Business \& Finance that included all Irish registered firms in manufacturing and services, irrespective of ultimate ownership (that is, including Irish owned firms, foreign owned subsidiaries and government owned firms). ${ }^{48}$ As these lists are compiled from official data, some large Irish firms are not included because of Ireland's business registration laws. Irish firms that register as 'unlimited' firms (i.e. firms that waive the protection of limited liability) are not required to publically report financial data. A number of very large family owned firms have for reasons of privacy availed of this registration status in recent years. In such circumstances, we draw on other sources, including company websites, to identify or estimate revenues.

In creating this dataset of Ireland's largest firms, decisions were required on two dimensions: (i) which sectors to include, and (ii) whether foreign-owned and state-owned firms should be included. In terms of sectors, recent SSOP studies have argued that the focus of research should be broadened to include service firms. ${ }^{49}$ Manufacturing and service firms are included, though following previous studies, financial firms are not included, as comparisons are difficult as size is often measured based on assets held or managed rather than revenues. Some recent SSOP studies have included foreign-owned firms on the basis that large foreign subsidiaries and ownership by foreign firms is increasingly common. ${ }^{50}$ As noted above, Ireland's industrial development strategy has resulted in a large number of foreign-owned firms operating in Ireland, in excess of 1,000 firms, with the ten largest firms by revenue in Ireland in 2010 including six foreign owned firms, such as Microsoft Ireland and Google Ireland. ${ }^{51}$ Foreign owned firms are not included in this study, as (i) strategy is typically the outcome of decisions made outside of Ireland, (ii) the firms are typically not deeply embedded into the Irish economy, in terms of linkages with indigenous firms, ${ }^{52}$ and (iii) the very high revenues these firms report in Ireland are influenced by accountancy practices designed to minimise global corporate taxation liabilities.

The Irish government has majority ownership in a number of commercial enterprises. The Irish government's industrial policy initiatives included the establishment of firms in the utilities and infrastructure sector, such as energy, peat processing, and postal services; in the transport sector, such as bus, rail and airlines; and in services, such as broadcasting and the national stud. A number of those firms created by the state have partly or wholly transferred from state ownership to private ownership through a process of privatisation, and where this has occurred they are included in the study. Some however remain in state ownership and by virtue of natural monopolies or licencing laws remain large, and have revenues comparable to some of the fifty largest firms. These firms differ from privately owned businesses in that their strategic mandate is determined 
by the sole or majority shareholder, the Irish government. Firms where the state has a majority ownership are excluded from the study. The impact of this may not be large as according to Faccio and Lang, Ireland (and the UK) 'stand apart' from other Western European countries in that there are a relatively low number of firms in Ireland that are state controlled (less than $1 \%$ of the 69 firms included in their study). ${ }^{53}$

The fifty largest firms in Ireland had a combined turnover of $€ 11,053 \mathrm{~m}$. in 1978, growing to $€ 26,979 \mathrm{~m}$. in 1990 and to at least $€ 70,246 \mathrm{~m}$. in $2010^{54}$ (constant 2010 euros). ${ }^{55}$ This is a 5.9\% compound annual growth rate. In terms of size range, the annual revenues of the fifty largest Irish owned firms ranged from $€ 140 \mathrm{~m}$. to $€ 17,173 \mathrm{~m}$. in 2010 , and from $€ 99 \mathrm{~m}$. to $€ 685 \mathrm{~m}$. in 1978 . The average revenue per business in each time period was $€ 221 \mathrm{~m}$., $€ 540 \mathrm{~m}$., and $€ 1,634 \mathrm{~m}$. in 1978, 1990, and 2010 respectively. Using the 2010 Fortune 1000 list as a comparator, one Irish firm (CRH) in 2010 was large enough, in terms of revenues, to be on the Fortune 100 list, five to be on the Fortune 500 list, and sixteen to be on the Fortune 1000 list. The revenues of the largest 50 firms were equivalent to $30 \%$ of Irish Gross National Product in 1978, 42\% in 1990, and at least 50\% in 2010.

\section{Classifying the strategic dimensions of firms - SSOP framework}

In terms of strategy, firms are classified into one of four categories: single, dominant, related diversified, and unrelated diversified. Single firms are those that have grown by the expansion of one product line and where $95 \%$ or more of total sales lie within a single business. Dominant firms have between $70 \%$ and $95 \%$ of revenues in one core business, with the remainder in a related or unrelated business. Firms that are diversified have no one single business activity accounting for more than $70 \%$. Related implies that there are market or technological relatedness, including vertical integration, between at least $70 \%$ of business activity. Unrelated implies that there are no significant market or technology relatedness for at least $30 \%$ of the business.

The firms are classified into one of four internationalisation categories: home market orientated implies less than $10 \%$ of revenue generating activities are abroad; partly home market orientation means that between $10 \%$ and $50 \%$ of revenue generating activities are abroad; partly international orientation mean that between $50 \%$ and $90 \%$ of revenue generating activities are abroad; and international orientation means that foreign activities account for more than $90 \%$ of revenues.

To classify ownership we draw on annual reports and the FAME database. Ownership is based on the classification of firms either as dispersed or concentrated, using a $10 \%$ threshold. ${ }^{56}$ Dispersed firms have no single owner who owns or controls more than $10 \%$ of the firm. Concentrated firms are then classified in terms of the single largest shareholding. The categories are: family (which include instances of a single individual such as a founding entrepreneur), cooperative (co-operative members are collectively the largest shareholders), other firm (a nonfinancial firm), finance (a financial firm, such as an investment firm or pension fund) and bank. In addition we also classify firms in terms of whether their shares are traded on a public stock market.

The analysis of the data focusses on the general trends across the three time periods for the strategy, international and ownership categories and additionally, following Iversen and Larsson summary results of tests for differences across the three years using the Pearson chi $^{2}$ test are included in the tables. Iversen and Larsson (2011) calculated indices of diversification and international based on 'simple weighted averages' and tested for differences. Their approach is replicated, with the approach and tables reported in Appendix 2. Finally, the strategic attributes of 
the largest Irish firms in 2010 are compared to the studies of the top 25 firms in Denmark and Sweden (2008), and the top 50 firms in Italy (2002), the Netherlands (2003), and Spain (2002).

\section{Classifying firms by sector}

The sector of activities of each firm was initially classified in terms of 4 digit NACE codes. This involved a classification of the firm based on secondary data sources. For the earlier two time periods this involved, where possible, published annual reports, and in other cases newspaper achieves from the time. For 2010 we draw on published annual reports and website material. We aggregated all firms into the following sectors: Agriculture, forestry and fishing; Mining and quarrying; Manufacturing (food products, beverages); Manufacturing (including textiles, wood, paper products); Manufacturing (including pharmaceuticals, plastics, metals, electrical, transport); Utilities; Construction; Wholesale and retail; Transport (including airlines); Publishing, arts, entertainment; and Services. Given the importance of the food and beverage sector in Ireland we separated out these manufacturing firms from other manufacturing firms.

The changing sector composition of large firms is analysed in terms of Eurostat definitions of technology and knowledge intensity and then for the manufacturing firms, Peneder's two empirically driven taxonomies of manufacturing industries. Using NACE 2-digit level codes manufacturing sectors were divided into the following Eurostat classifications: High-technology, Medium-high-technology, Medium-low-technology, and Low-technology; and service firms were classified into either Knowledge-intensive services (KIS) or Less knowledge-intensive services (LKIS). Knowledge-intensive services (KIS) sub divide into Knowledge-intensive market services, High-tech knowledge-intensive services, Knowledge-intensive financial services, and Other knowledge-intensive services; and Less knowledge-intensive services (LKIS) sub divide into Less knowledge-intensive market services, and Other less knowledge-intensive services. ${ }^{57}$ The manufacturing firms were classified using Peneder's two empirically driven taxonomies of manufacturing industries - one that reflects expenditures on capital, labour, R\&D, and advertising (Mainstream manufacturing (MM); Labour intensive industries (LI); Capital intensive industries (CI); Marketing driven industries (MDI); Technology driven industries (TDI)) and a second that is based on typical requirements for skilled labour (High; Medium - White collar; Medium - Blue collar; Low).

\section{Application of the SSOP framework in the Irish context}

In order to analyze the strategic transformations in large firms in Ireland this section focusses on the strategic dimensions of the SSOP framework: (i) ownership regimes, (ii) strategic orientation, and (iii) international orientation of large Irish firms for three bench mark years, 1978, 1990 and $2010 .{ }^{58}$ In each case we explore the changes observed across the three time periods, noting whether there is evidence of convergence within the sample, and we compare the 2010 results for Ireland to findings from other European countries. The comparative data is drawn from published studies from Denmark (2008), Italy (2002), the Netherlands (2003), Spain (2002), and Sweden (2008). ${ }^{59}$ As sample sizes differ across studies we report findings for both the largest 50 Irish firms and the largest 25 Irish firms (comparative data on the 50 largest firms is available for Italy and Spain, while for Denmark, the Netherlands and Sweden comparative data is available for only the 25 largest firms).

\section{Ownership regimes}


Family ownership has remained an important ownership structure in Western Europe, particularly in industrial firms in continental Europe. ${ }^{60}$ Family ownership is the most important ownership structure among the largest firms in Ireland in each of 1978 (48\%), 1990 (38\%) and $2010(44 \%)$ (Table 1). The statistical tests reported in this paper identify statistically significant differences among ownership types (Table $1 ; p=0.051$ ). Family ownership is prevalent in different sectors of activities, though it is particularly strong in sectors with a large domestic market, such as wholesale, retail, and construction. The most prominent change from 1978 to 2010 is the decline in the number of co-operative firms (from fourteen to three firms). There was an increase in firms with ownership characterised as concentrated-firm (an increase of six firms) and those with ownership characterised as concentrated-finance (an increase of six firms) between 1978 and 2010. A further notable trend has been an increase in the number of businesses listed on a stock exchange (typically on the Irish, London, or a US stock exchange). In 1978, 30\% of the firms were listed on a stock exchange (most typically the Irish stock exchange). By 2010 this had increased to $54 \%$ of the firms.

Comparing the ownership regimes of large Irish firms in Ireland to those of other European countries is difficult as there is variation in the sampling choices made across studies. If state and foreign firms are excluded from the largest 50 firms in Italy and Spain, family (personal) ownership dominates ( $84 \%$ and $42 \%$ respectively), with very few firms classified as dispersed ownership $(0 \%$ and $8 \%$ respectively). This pattern is similar in Sweden (62\% family and $12 \%$ dispersed), though Denmark is characterised by a different ownership structure, with foundations and co-operatives dominating (63\%). Dispersed ownership in large firms is more prevalent in Denmark (21\%) than it is in Italy, Spain or Sweden. In Ireland, family ownership is therefore less common (44\%) and dispersed ownership more common (16\%) relative to Italy, Spain or Sweden (Table 2).

\section{Insert Table 1 \\ Table 1: Ownership, strategic orientation and market orientation, Ireland}

\section{Insert Table 2 \\ Table 2: International comparisons of ownership, strategic orientation and market orientation}

\section{Strategic orientation}

Chandler's research reported that the pattern of growth of the largest US manufacturing firms was one of related diversification. Prior SSOP research has argued that large firms in France, Germany, and the UK have also been characterised by a strategy of diversification. ${ }^{61}$ Such a strategy is consistent with Penrose's resource theory of growth (1959), in which she argues that firms move into new technologies and markets as they develop excess managerial resources. ${ }^{62}$ In Ireland the primary strategic orientation in each time period is single business $(58 \%, 44 \%$ and $48 \%$ in 1978 , 1990, and 2010 respectively) (Table 1). The statistical tests reported in this paper find no significant differences for strategic orientation across the three benchmark years (Table 1) and consistent with this, the f-tests included in Appendix 2 find no statistically significant differences for the strategic orientation (diversification) index (Table A2, Appendix 2). The data for 2010 indicates that the single and dominant business strategy, whether in home or international markets, is more important that the related diversification strategy.

The importance of the single or dominant strategy in Ireland may be explained by two factors. First, the firms in the Irish sample are typically smaller than the largest firms in large 
economies such as the US, the UK, Germany and France. As noted above, just one Irish firm would be of a requisite size for inclusion in the 2010 Fortune 100 list. Smaller firms may benefit from pursing a product specialization strategy across geographically diverse markets. The strategy literature contends that firms should 'stick to knitting', 'focus' or exploit their 'core competencies'. ${ }^{63}$ Second, as discussed below, many of the fifty largest firms in Ireland in 2010 have not been large for a long period of time. Many of the large firms in 2010 grew in size during the recent period of economic integration. As argued by Penrose, strategies of related diversification might emerge as firms reach the limits of geographical expansion and as they develop excess resources. ${ }^{64}$

With respect to strategic orientation, the largest 50 firms in Ireland are more likely to be pursuing a single or dominant strategy (72\%) compared to Italy, the Netherlands and Spain (40\%, $21 \%$ and $42 \%$ receptively). However, in Denmark and Sweden there is also a high percentage of firms pursuing such strategies (84\% and 52\% respectively) (Table 2).

\section{Market orientation}

Increased integration within Europe has resulted in increased intra-European trade, with large firms characterised by increased internationalisation. ${ }^{65}$ The most notable strategic transformation in the fifty largest firms in Ireland is the increase in the number of firms that are international in orientation (Table 1) (Table 2A, Appendix 2). ${ }^{66}$ In 1978, 48\% of the largest Irish firms were characterised as home market orientated, with a further $28 \%$ characterised as partly home market orientated (greater than half of total revenue from home market). By 1990, 22\% of the largest firms were home market orientated and $24 \%$ were partly home market orientated. This trend continued until 2010, when $14 \%$ of the firms were home market orientated, and $26 \%$ partly home market orientated. In summary, while $76 \%$ of firms were predominantly competing on the home market in 1978, less than half were in both 1990 (46\%) and 2010 (40\%). The statistical tests reported here find statistically significant differences among market orientation types (Table 1; $\mathrm{p}<0.00$ ). Consistent with this, the f-tests included in Appendix 2 show a statistically significant difference for the market orientation (internationalisation) index (Table A3, Appendix 2).

The increased international orientation of the fifty largest firms included both an increase in the number of firms that have a partly international orientation and those that have an international orientation. This later group grew from one firm (2\%) in 1978, to three firms (6\%) in 1990, to nine firms (18\%) in 2010. The increase in international activity occurs in the context of a relatively small domestic market that compels some firms to expand internationally; the changed external institutional context of increased European integration; and a consistent focus of Irish industrial policy on exporting and internationalization. More of the largest 50 firms in Ireland are pursuing an international or partly international strategy (60\%) compared to Italy (30\%) and Spain (30\%), though a higher number of the fifty largest listed firms in the Netherlands and the largest twenty five firms in Denmark and Sweden have an international or partly international strategy (71\%, $72 \%$ and $80 \%$ respectively) (Table 2 ).

\section{Combinations of strategic orientation and market orientation}

These transformations observed in the longitudinal analysis of large Irish firms include a trend towards international expansion in product specialisms. The interactions between strategic orientation and international orientation show that there are a number of large businesses that are characterized by a single or dominant strategic orientation and by a home or partly home market orientation (52\% in 1978, 36\% in 1990, and 32\% in 2010) (Table 3). While this was the most 
frequent strategy-internationalization combination in 1978 and 1990, a greater proportion of firms (40\%) in 2010 were characterized by a single or dominant strategic orientation and by a partly international or international market orientation. The statistical tests reported in this paper reveal a statistically significant interaction between strategic orientation and international orientation (Table $1 ; \mathrm{p}=0.001$ ). Internationalisation via a strategy of product specialism is consistent with research that suggests that in a European context, the general trend towards related diversification identified by Chandler may not apply in the context of smaller firms seeking to grow internationally. ${ }^{67}$

Within the dataset there are a number of large businesses that are home or partly home market orientated. These firms are typically characterized by family ownership; they have not pursued a strategy of diversification; and are most evident in the wholesale and retail sector and the construction sector. The persistence of this form of business organization is consistent with evidence from Sweden. ${ }^{68}$ There are a number of possible explanations for the persistence of this business organisation. First, economic integration may have impacted on the financial performance rather than on the survival of these firms. As discussed below, firms that are home or partly home market orientated perform less well than large firms that are partly international or international. Family-owned firms may be able to sustain lower returns on capital than publically quoted large firms. Second, in some sectors, the preferred mode of market entry may be acquisition of an established business, and given the family or private ownership that characterizes many of these domestic focused businesses, families may block entry by foreign firms. Third, barriers to entry, high capital costs, low margins, and small market size may make some sectors and markets unattractive to international firms, reducing entry by international competitors.

Analysis of the dataset provides some evidence that firms characterised by a home or a partly home market orientation perform less well than those that are partly international or international. While some of the firms do not report their financial performance data, the 2010 data shows that for firms that are home or partly home market orientated, ${ }^{69}$ returns on assets and returns on sales are lower than for firms that are partly international or international orientated $(2.4 \%$ compared to $4.2 \%$ for return on assets, $1.2 \%$ compared to $4.6 \%$ for return on sales). This performance difference is evident in the 1978 data as well, though performance data is not available for over half of the firms. ${ }^{70}$ In 1978 , firms that were home or partly home market orientated had lower returns when compared to firms that were partly international or international orientated $(7.4 \%$ compared to $9.7 \%$ for return on assets, and $1.0 \%$ compared to $5.3 \%$ for return on sales). An important caveat to this comparison of performance is that differences may be due to other factors, such as differences in sector, rather than differences in levels of internationalization.

\section{Insert Table 3 \\ Table 3: Patterns of strategy and internationalisation, Ireland}

In summary, the application of the SSOP framework in the Irish context finds that during the period 1978 to 2010 there is no evidence of a universal business organization among the largest Irish firms. ${ }^{71}$ While strategies of internationalization have become more important among firms over the time period, and there is evidence of some firms pursuing a strategy of internationalisation through product specialism, there is no universal business organisation in Ireland. In Ireland, family ownership has remained the dominant ownership regime. Within other forms of concentrated ownership there has been a reduction in co-operatives and an increase in the number 
of firms with concentrated ownership with another firm or a financial institution. The strategic characteristics of the largest Irish firms in 2010 differ in some respects to the evidence from other European countries (Table 2). While the pattern of business organization in Ireland in 2010 with regard to strategy and internationalization is similar to that in other small European countries (Denmark and Sweden), it differs from those observed in Italy and Spain.

\section{Limitations of the SSOP framework in the Irish context}

As noted earlier, the SSOP approach has been criticized for being 'without geography' 72 and 'timeless', ignoring, for example, how variations in historical patterns of industrial development, differences in natural resources, and differences in institutions have resulted in differing sector profiles across countries. ${ }^{73} 74$ The strategic transformations in large firms identified above are discussed in terms of two factors: (i) the sector of activity of large firms for each of the three benchmark years; and (ii) churn in the firms listed among the fifty largest Irish firms. Both of these factors provide insights into the findings from the previous section's application of the SSOP framework to Ireland. This is followed by four case studies, selected from different sectors, each of which illustrates the transformation of a large firm included in the 2010 dataset.

\section{Sectors of activity of large Irish firms}

The fifty largest firms in Ireland for 1978, 1990, and 2010 are summarised below by NACE sector (Table 4), ${ }^{75}$ by Eurostat technology and knowledge intensity classifications (Table 5), and by Peneder's classification of manufacturing sectors (Table 6). In 1978, 82\% of large firms in Ireland were in either Low-technology manufacturing sectors or Less knowledge-intensive market services (Table 5) with just two broad industrial categories (manufacture of food and beverages; and wholesale and retail trade) together accounting for $74 \%$ of the large firms in 1978 (Table 4). By way of comparison, among the largest 100 firms in Italy and Spain, in 1973 these two sectors combined accounted for just $24 \%$ and $23 \%$ respectively. ${ }^{76}$

The prominence of manufacturing of food and beverages, in particular, reflects the industrial legacy inherited by the newly independent Irish Free State in the 1920s: an Irish industry predominantly focussed on agriculture and manufacture of goods based on the processing of agricultural raw materials (such as brewing, distilling, bacon curing, biscuits, sugar production), in which agricultural output, food, and beverages accounted for $86 \%$ of Irish exports. ${ }^{77}$ This agricultural past is evident in large firms in 1978, as 11 of the 19 food processing firms are organised as dairy co-operatives and are indicative of an Irish co-operative movement whose origins can be traced back to the 1890 s. $^{78}$

The EEC's Common Agricultural Policy (CAP), however, inevitably led to significant changes in both structure and strategy of these Irish food processing co-operatives. Following the introduction of milk quotas in 1984 aimed at reducing the quantities of dairy products destined for intervention, Irish dairy producers began to adopt new corporate strategies based on diversification and internationalisation which would see them reduce their dependence on milk production and focus instead on global consumer food markets. ${ }^{79}$ These changes are evident in our dataset. For example, in terms of strategy, in the food and beverage sector single business strategy firms accounted for nine of nineteen firms in 1978, but single business strategy firms account for just one of the nine food and beverage firms in 2010. The pursuit of international expansion in this sector is evident in the change in the number of firms with a partly international or international orientation. Thirteen of the nineteen firms in the manufacturing of food and beverages sector in 
1978 were either home or partly home market orientated. Of the nine the food and beverage firms in 2010 just one was classified as were either home or partly home market orientated.

In terms of ownership, co-operative ownership characterised firms in the manufacturing of food and beverages, specifically firms involved in the dairy industry. Over time, many of the larger co-operatives changed their legal status from co-operative to limited liability public firm, with the co-operative members becoming shareholders in the new firm. By 1990, four of the largest six cooperatives had gone public and adopted a public limited company ownership structure, while the other two had amalgamated. In 2010, the top 50 largest firms contains only nine food processing firms, as co-operatives came to be subsumed into larger indigenous food producers.

In addition to food and beverage manufacturing firms in 1978, two other manufacturing sectors are also represented in the largest firms in 1978, though less prominent than those of agricultural origins: manufacture of textiles, wood and paper products (8\% of firms in 1978, $6 \%$ in 2010) and manufacture of chemicals, pharmaceuticals, plastics, metals, and electrical products (6\% of firms in 1978, $8 \%$ in 2010). The former comprise of high-bulk, low-value goods such as carpet and furniture, and those that were large in 1978 are indicative of that minority of indigenous firms which were formed in the protectionist era of the 1930 to 1950 s and were able to survive the subsequent competitive environment. ${ }^{80}$ In the manufacturing sector (excluding manufacture of food and beverage) five of the seven firms in 2010 were classified as pursuing a single or dominant strategy.

The second important sector in Ireland in 1978 was wholesale and retail trade, a less knowledge-intensive market services sector. Firms in less knowledge-intensive market services account for at least one third of all the firms in each of the three benchmark years $(36 \%, 40 \%$ and $40 \%$ in 1978, 1990, and 2010 respectively). Even though there was churn in the firms in the wholesale and retail sector, the majority of firms in each time period were characterised as pursing single or dominant strategies (16 firms in 1978, 18 firms in 1990, and 16 firms in 2010). The increased internationalisation of Irish firms is evident in this sector. In 1978 firms in the wholesale and retail sector were predominately home market orientated (16 of 18 firms), while by 2010 just seven of the eighteen wholesale and retail firms were predominately home market orientated.

Outside of the wholesale and retail trade sector, service firms (including transport, publishing, arts, entertainment, professional and scientific) were less prevalent in 1978, with just two of the fifty largest firms (4\%) in that year operating in the services sector. By 2010 eight firms of the fifty $(16 \%)$ were active in the services sector (though they accounted for just $9 \%$ of total revenues). Seven of these eight services firms were included among the fifty largest firms for the first time in 2010, while the eighth firm was already a large firm in 1990. Among the services represented are transportation, media and entertainment, clinical testing, and business support services. ${ }^{81}$ In addition, two utility firms were among the fifty largest firms in 2010 (no non-state owned utility firms were among the largest firms in the 1990 or 1978). The strategic transformations observed in the SSOP analysis reflect the emergence of large firms in the services sector. Six of these eight firms in 2010 were characterised by a single or dominant strategy. The emergence of large services firms may reflect EU-wide efforts to introduce a single market in services and to deregulate services and capital markets since the 1980s.

While both the consolidation observed among large firms in a number sectors and the emergence of large firms in the service sector provide insights into the strategic transformations reported from the application of the SSOP framework to Ireland, the Eurostat technology classifications also illustrates that the majority of large Irish firms in 2010 were still classified as operating in either low-tech manufacturing sectors $(24 \%)$ or less knowledge-intensive market 
services (40\%) (64\% combined, compared to $82 \%$ in 1978) (Table 5). While there was a decrease in the number of manufacturing firms in total, from 26 in 1978 to 16 in 2010, the absolute number of firms in medium-low-technology, medium-high-technology or high-technology sectors remained small (3 in 1978; 4 in 2010) (Table 5). Based on Peneder's skill type classifications, nine firms were in sectors classified as medium blue collar, medium white collar or high skilled in 2010, compared to six firms in 1978 (Table 6).

\title{
Insert Table 4 \\ Table 4: Fifty largest firms by sector, Ireland
}

\author{
Insert Table 5 \\ Table 5: Fifty largest firms by technology and knowledge intensity, Ireland \\ Insert Table 6 \\ Table 6: Manufacturing firms by Peneder's classification, Ireland
}

\section{Churn in the firms listed in the fifty largest Irish firms}

As noted above Ireland is characterised by "late industrialisation" and by significant state investment in supporting the development of indigenous firms. A notable characteristic of the Irish data is that there is significant churn in the firms represented in each of the three benchmark years. The patterns of strategy, internationalisation and ownership observed in the SSOP analysis may reflect a common pattern of business organisation in the large number of firms that enter the list of large firms in 2010, firms that that were not in the top fifty largest firms in 1978 and/or may reflect the pattern of business organisation in the small number of firms that remain in the dataset across the three bench mark years.

Thirty one $(62 \%)$ of the fifty largest firms in 2010 were not among the fifty largest firms in 1978, though six of these enter the list due to changes in ownership. ${ }^{82}$ The twenty five firms that were new to the list of the 50 largest firms in 2010 either did not exist in 1978, or they were not large enough in 1978 to appear in the list of the fifty largest firms. Examples include firms such as Cpl Resources (recruitment, staffing and outsourcing services), Dragon Oil (oil and gas exploration), Icon (services to the pharmaceutical, biotechnology and medical device industries), KINGSPAN (manufacturer of insulation products), M\&J Gleeson (Investment) Ltd (manufacturer of soft drinks), and Paddy Power plc (sports betting operator). These firms are characterised by single or dominant strategic orientation (17 (68\%) of the 25 firms). However, there is no pattern in terms of international orientation, with eleven firms (44\%) characterised by home market or a partly home market orientation, and fourteen firms (56\%) characterised as partly international or international orientation. The firms operate in a range of sectors, with nine firms (36\%) in the wholesale and retail sector, six firms (24\%) in service sectors (including transport, publishing, arts, entertainment, professional and scientific), and three firms (9\%) in each of manufacture of food and beverages and other manufacturing. In terms of ownership, fourteen are listed on a stock exchange and ten of the remaining eleven are family owned firms. The listed firms are relatively young, with eleven created since 1960 (though this includes one firm that emerged as the result of a merger of older firms). In contrast, of the ten family owned firms, seven have origins that predate 1960, while one is a merger of three firms that each pre-date 1960. 
Just eleven firms that were large in 2010 featured among the fifty largest firms in $1978 .{ }^{83}$ Of the eleven firms that were large in 1978 and 2010, there is no evidence of a universal business organization across these firms. Reflecting the dominance of food manufacturing and wholesale and retail firms in the 1978 largest firms, eight of the eleven firms come from these two sectors. Four large food co-operatives (Avonmore, IAWS, Kerry, Waterford) in 1978 appear as three independent firms on the 2010 list of large firms (Glanbia, Kerry Group, and Origin Enterprises). As noted above, these co-operatives changed from co-operative to public ownership, each listing on a stock exchange during the 1990s. Each of the firms pursued a strategy of international expansion, involving acquisition of firms outside of Ireland. In addition, a family owned food manufacturer (Arlesse) that remained large pursued a strategy of internationalisation and of related diversification. In contrast to the firms in the food manufacturing sector, the four firms present in the dataset in each of the three time periods in the domestic wholesale and retail sector (a sector with a large domestic market) were family owned private firms (Dunnes Stores, Musgrave Group, O'Flaherty Holdings, and Tedcastle Holdings). These firms focused on the domestic market and pursued a single or dominant business strategy. Of the other three firms that remained large across the benchmark years, they are each characterised by increased internationalisation, though they differ in terms of ownership, with one family owned construction firm (Sicon) and two publically listed manufacturing firms (CRH and Smurfit Kappa). ${ }^{84}$

\section{Case studies of large Irish firms}

Short case studies of four large Irish firms from the 2010 dataset illustrate the patterns of changes in ownership, strategy and internationalisation discussed above. One case is selected from each of four separate sectors (manufacture of food and beverages; wholesale and retail trade; other manufacturing; and services). Three of the four cases (Glanbia plc., Musgrave Group, CRH plc) are firms that were large in 1978, and remained large in 2010, while the fourth case (Ryanair plc) appears on the list of large firms for the first time in 2010.

Illustrative of the patterns of transformation of ownership, strategy and internationalisation discussed above is the evolution of Glanbia plc., one of Ireland's largest ten firms in 2010. Glanbia, a public firm listed on the Irish and London Stock Exchanges, describes its strategy as an 'international nutritional solutions and cheese group'. In 1964, Waterford Co-operative, the first large Irish co-operative, was created as a result of the merger of five smaller co-operatives, while Avonmore Co-operative was created in 1966, the result of a merger of twenty five small cooperatives. These two large co-operatives were included in the 1978 list of large firms. Both cooperatives changed their ownership structure in the 1980s, becoming public firms listed on the Irish stock exchange. By 1990 both firms were included in the ten largest firms in Ireland (combined turnover $€ 1,961$ m., 2010 euros). The two firms subsequently merged in 1997 to become Glanbia. As co-operatives, both Avonmore and Waterford operated as dairy processors, principally in butter and milk. As public firms they grew by expanding in the Irish market, including the liquid milk market, and by expanding, via acquisition, into new international markets. Since the merge, Glanbia has changed strategic focus, by emphasizing international opportunities in the growing food ingredients market (e.g. manufacturing mozzarella cheese for pizzas). This has involved divesting a number of businesses, including the UK liquid milk business, and divisions in Ireland in Irish beef processing, in processed meat, and more recently, in fresh meat operation. 
In the wholesale and retail of food, the family owned Musgrave Group plc. has grown large by expanding within the Irish market. In 2010, Musgrave is one of Ireland's ten largest firms, with revenues of $€ 4,386 \mathrm{~m}$. Musgrave Group is the largest wholesale grocery distributor in Ireland and is the franchiser of two leading Irish grocery chains. Founded in 1876, this family owned firm has grown by expanding within the Irish market, first in the late 1950s when it focused on a new wholesaling format, 'cash and carry', which resulted in it appearing on the 1978 list of largest Irish firms ( $€ 1,866 \mathrm{~m}$., 2010 euros). The firm continued to grow in the 1990s when it focused on a new retail format of voluntary group participation for both local small convenience food stores and for larger food supermarkets (whereby retailers pledged to buy from the Musgrave Group). More recently the firm has expanded internationally (in the 1990s the firm acquired a Spanish supermarket chain, and in the 2000s it acquired a chain of small grocery stores in the UK), though it is still predominately focused on the Irish market.

$\mathrm{CRH}$ plc is a manufacturing firm that has grown rapidly by pursuing a strategy of international acquisition. CRH plc, a publically listed company, is Ireland's largest firm in 2010, with revenues of $€ 17,173 \mathrm{~m}$., and it was large in 1990 (€2,540 m.) and in 1978 (€524 m.). The firm was created in 1970 when two publically listed firms, Roadstone (founded in 1949) and Cement Ltd (founded in 1936) merged. In 1970 the two merging firms operated nearly exclusively in the Irish market. CRH's growth occurred through a strategy of international acquisition. In $1973 \mathrm{CRH}$ began a strategy of international acquisition, acquiring businesses in the Netherlands. Expansion continued into the UK, the US and other markets. The businesses expanded into related areas such as construction related products and the distribution and sale of builders supply to the construction industry. Growth was by acquisition of small to medium sized established local businesses. By $1978,18 \%$ of CRH's revenues were outside of Ireland, though ten years later, in 1990, this had increased to $81 \%$ of revenues. By 2010 the Irish market accounted for less than $4 \%$ of revenues.

Ryanair plc., is one of Ireland's ten largest firms in 2010, yet it did not exist in 1978, and was still a small firm in 1990 (approximately €85 m. constant 2010 euros). Ryanair plc., a publically owned low cost airline, was founded in 1985 by members of the Ryan family. Ryanair's initial strategy to compete on routes between Ireland and the UK was not successful, with the firm experiencing financial losses. In 1993, the financial controller, Michael O'Leary, became CEO and under his direction, Ryanair pursued a 'low cost' strategy, exploiting the opportunities created by the European Union's completion (in 1996) of the 'Open Skies' deregulation of the scheduled airline business. In 1997, Ryanair became a public firm, listing on the Dublin and NASDAQ exchanges. Ryanair pursued a strategy of expanding its route network and bases from Ireland into the UK, including intra-UK flights, and then into European destinations and into European bases.

\section{Discussion and conclusions}

Consistent with arguments that geography and time influence the nature of business organisation, research using the SSOP framework has demonstrated that large firms in some national contexts have not been characterised by convergence to a universally applicable business organisation. This study explores the continued resistance to convergence to a universally applicable business organisation by analyzing the strategic transformations in large firms in Ireland. The Irish context offers insights in this regard as it is characterised by late industrialisation and, in recent decades, by increased European integration.

Using three benchmark years, 1978, 1990 and 2010, this study finds that there is no evidence of a universally applicable business organization in the Irish context. The pattern of business 
organization in Ireland in 2010 with regard to strategy and internationalization is similar to that in other small European countries (Denmark and Sweden), with evidence that strategies of internationalization have become more important over the time period. While family ownership remains the dominant ownership regime, within other forms of concentrated ownership there has been a reduction in co-operatives and an increase in the number of firms with concentrated ownership with another firm or a financial institution/bank.

Two factors, sector of activity and churn in the firms listed in the fifty largest Irish firms, provide an insight into the strategic transformations observed in the SSOP analysis. In terms of sector of activity, two sectors are particularly important across the three time periods: the manufacturing of food and beverages and wholesale and retail. Changes within the manufacturing of food and beverages sector include changes in ownership regime, a move away from co-operative ownership to publically owned firms, and increased internationalization via a dominant strategy. Within the wholesale and retail sector there is evidence of the persistence of a single or dominant strategy, variety in ownership regime, and increased internationalisation. A further notable change in Ireland has been the increase in the number of firms in the services sector. In terms of changes in the firms listed in the fifty largest Irish firms, there was a significant churn, with twenty five of the fifty large firms in 2010 not large in 1978. However, within this group of new firms and within the group of large firms that remained large across the three benchmark years, there was no universally applicable business organisation.

Even in the context of an SSOP analysis that suggests strategic transformations in large Irish firms, and an analysis that shows that there has been significant churn among the largest fifty firms across the benchmark years included in this study, a more detailed sector analysis highlights that large Irish firms are in sectors that are characterised as low-technology manufacturing sectors and less knowledge-intensive market services, and that this profile has persisted across the three benchmark years. For example, focusing solely on manufacturing firms (which includes food and beverages), and using Peneder's skill-based classification, 79\% of manufacturing firms in 1978 were in low skill sectors; while using Peneder's classification based on expenditures on capital, labour, advertising, and R\&D, demonstrates that just one Irish manufacturing firm was classified in capital intensive sectors and no firm was classified in technology driven sectors in 1978. By 2010 nearly half of manufacturing firms were classified in low skilled sectors, and just one firm was classified in technology driven sectors. This indicates that aspects of Ireland's industrial legacy have had a persistent impact of the business organisation of large firms in Ireland. Given the importance of sector as a contextual factor in understanding ownership, strategy and internationalisation changes in large Irish firms, future work could explore the extent to which the largest firms in Ireland reflects Ireland's revealed comparative advantage informed by Ireland's industrial and agricultural past.

More generally, this study contends that SSOP research needs to respond to Whittington and Mayer's call for 'increased contextual sensitivity' in a number of specific ways. ${ }^{85}$ First, the SSOP research should include a focus on the dynamics within a national context that influence business organization. For example, by including sector classifications in an SSOP study, the analysis can explore if strategic patterns or ownership regimes are particular to important sectors in a given context. Second, SSOP research should explore the impact of churn in large firms on the pattern of business organisation observed in SSOP studies. For example, do strategic transformations and changes in ownership regime reflect within-firm changes overtime? Or do they reflect changes in the composition of firms, as new large firms may adopt new forms of business organisation. This requires a greater focus on firm dynamics between time periods, and increased attention on the 
business organisation of firms experiencing different trajectories with respect to their relative position vis-à-vis the largest firms within a given country.

\section{Acknowledgements}

We wish to express our gratitude to the two anonymous reviewers for their incisive and constructive comments. We thank two research assistants, Ms. Celine Craddock and Mr. Rowan Finch, who helped with our data collection. 


\section{Bibliography}

Barry, F. 2002, "The Celtic Tiger Era: Delayed Convergence or Regional Boom”, ESRI Quarterly Economic Commentary, Summer. Dublin: The Economic and Social Research Institute.

Barry, F. 2014, "Diversifying External Linkages: the Exercise of Irish Economic Sovereignty in Long-Term Perspective", Oxford Review of Economic Policy, 30(2), 208-222.

Barry, F., Bradley, J. and O'Malley, E. 1999, "Indigenous and Foreign Industry: Characteristics and Performance", in Barry, F. (ed.) Understanding Ireland's Economic Growth, London: Macmillan Press.

Barry, F., Görg, H., and McDowell, A. 2003, "Outward FDI and the Investment Development path of a late-industrializing economy: Evidence from Ireland". Regional Studies 37(4): 341-349.

Begley, T., Delaney, E. and O'Gorman, C. 2005, "Ireland at the Crossroads: Still a Magnet for Corporate Investment", Organizational Dynamics, 34(3), 202-217.

Bielenberg, A. and Ryan, R. 2013, An Economic History of Ireland since Independence. Oxford: Routledge.

Binda, V. 2013, The Dynamics of Big Business. Structure, Strategy and Impact in Italy and Spain. New York: Routledge.

Binda, V. and Iversen, M. 2007, "Towards a 'Managerial Revolution' in European Business? The Transformation of Danish and Spanish Big Business, 1973-2003”. Business History, 49(4), 506-530.

Castells, M. 1998. End of Millennium, The Information Age: Economy, Society and Culture, Vol. III. Malden, MA; Oxford, UK: Blackwell.

Chandler, A. 1962. Strategy and Structure. Chapters in the History of the American Industrial Enterprise. Boston: MIT Press.

Chandler, A. 1990. Scale and Scope. The Dynamics of Industrial Capitalism. Cambridge, MA: Harvard University Press.

Colli, A. and Larsson, M. 2014, "Family Business and Business History: An Example of Comparative Research", Business History, 56(1), 37-53.

Daly, M. 2014. The First Department: A History of the Department of Agriculture. Dublin: Institute of Public Administration, pp.1-14.

De Jong, A., Sluyterman, K. and Westerhuis, G. 2011, "Strategic and Structural Responses to International Dynamics in the Open Dutch Economy, 1963-2003", Business History, 53(1), 6384.

Dunning, J. 1981, "Explaining the international direct investment position of countries: towards a dynamic or developmental approach". Weltwirtschaftliches Archiv, 117: 30-64.

Dunning, J. 1986, "The investment development cycle revisited". Weltwirtschaftliches Archiv, 122: 667-677.

Enterprise Strategy Group 2004, Ahead of the Curve: Ireland's Place in the Global Economy, Dublin: Forfás.

Faccio, M. and Lang, L. 2002, "The Ultimate Ownership of Western European Corporations", Journal of Financial Economics, 65(3), 365-395.

Fligstein, N. 2008, "Chandler and the Sociology of Organisations", The Business History Review, 82(2): 241-250.

Fligstein, N. and Merand, F. 2002, "Globalization or Europeanization? Evidence on the European Economy since 1980", Acta Sociologica, 45(1), 7-22.

Forfás 2000, International trade and investment report, 2000. Report by Forfás to the Trade Advisory Forum and the Foreign Earnings Committee, December. Dublin: Forfás. 
Forfás 2012. Annual Report, 2012. Dublin: Forfás.

Görg, H., and Ruane, F. 2000, “An Analysis of Backward Linkages in the Irish Electronics Sector”, The Economic and Social Review, 31 (3): 215-235.

Hall, P. and Soskice, D. 2001, An Introduction to Varieties of Capitalism in Varieties of Capitalism. The Institutional Foundations of Comparative Advantage, by Hall, P. and Soskice, D. (eds.). Oxford: Oxford University Press.

Higgins, D. and Toms, S. 2011, "Explaining Corporate Success: The Structure and Performance of British Firms, 1950-84", Business History, 53(1), 85-118.

Honohan, P. and Walsh, B. 2002, "Catching up with the leaders: the Irish hare”, Brookings Papers on Economic Activity, (1), 1-57.

Industrial Policy Review Group, 1992, A Time for Change: Industrial Policy in the 1990s, Dublin: The Stationary Office.

Iversen, M. and Larsson, M. 2011. "Strategic Transformations in Danish and Swedish Big Business in an Era of Globalisation, 1973-2008”, Business History, 53(1), 119-143.

Katzenstein, P. 1983, “The Small European States in the International Economy: Economic Dependence and Corporatist Politics", in J.G. Ruggie (Ed.), The Antinomies of Interdependence (pp. 91-130). New York: Columbia University Press.

Kennedy, L. 1989, The Modern Industrialisation of Ireland: 1940-1988. Ireland: Dundalgan Press. Kogut, B. 1992. "National Organising Principles of Work and the Erstwhile Dominance of the American Multinational Corporation", Industrial and Corporate Change, 1(2):285-323.

Lee, J. 1989, Ireland, 1912-1985: Politics and Society, Cambridge University Press: UK.

Mayer, M. and Whittington, R. 2003, "Diversification in Context: A Cross-national and Crosstemporal Extension", Strategic Management Journal, 24(8): 773-81.

National Economic and Social Council, 1982, A Review of Industrial Policy (the Telesis Report), Report No. 64, Dublin: National Economic and Social Council.

OECD, 2006. OECD Economic Surveys: Ireland. Paris: OECD.

O'Gorman, W. and Cooney, T. 2007. "An Anthology of Enterprise Policy in Ireland”, Irish Journal of Management, 28 (2), pp. 1-28.

Ó Gráda, C. 1997, A Rocky Road: The Irish Economy since the 1920s. UK: Manchester University Press.

O'Malley, E. 1998, The revival of Irish Indigenous Industry 1987-1997, in T.J. Baker, D. Duffy, and F. Shortall (eds.), Quarterly Economic Commentary, April, Dublin: Economic and Social Research Institute, pp. 36-65.

O’Malley, E. 2004. "Competitive Performance in Irish Industry", Quarterly Economic Commentary, Winter.

Ó Riain, S. 2004. State, Competition and Industrial Change in Ireland 1991-1999, Economic and Social Review, 35(1): 27-53.

Peneder, M. 1999, "Intangible investment and human resources. The new WIFO taxonomy of manufacturing industry", WIFO Working Papers, No. 114, May.

Peneder, M 2000. "Intangible Assets and the Competitiveness of European Industries", in Buigues, $\mathrm{P}$, Jacquemin, A and J-F Marchipont (eds) Competitiveness and the Value of Intangible Assets, Edward Elgar: UK.

Penrose, E. 1959. The Theory of the Growth of the Firm, Oxford: Basil Blackwell. (Revised and reprinted, 1989, 1995, 2009).

Peters, T. and Waterman, R. 1982. In Search of Excellence: Lessons from America's Best-run Companies, Harper \& Row. 
Porter, M. 1980, Competitive strategy, New York: Free Press.

Prahalad, C. and Hamel, G. 1990, "The Core Competence of the Corporation", Harvard Business Review, 68(3): 79-91.

Rondi, L., Sleuwagen, L., and Vannoni, D. 2004, "Changes in the Industrial and Geographical Diversification of Leading Firms in European Manufacturing", in A. Dierx, F. Ilzkovitz, and K. Sekkat (Eds.), European integration and the functioning of product markets (pp. 61-112). Cheltenham: Edward Elgar.

Roper, S., Love, J., and D. Añón Higón 2006, “The determinants of export performance: Evidence for manufacturing plants in Ireland and Northern Ireland". Scottish Journal of Political Economy 53: 586- 615.

Teece, D. 1993, "The Dynamics of Industrial Capitalism: Perspectives on Scale and Scope", Journal of Economic Literature, 31(1): 199-225.

Wilson, J., Iversen, M., Schröter, H., Colli, A., Binda, V. and Antcliff V. 2007. "Mapping Corporate Europe: Business Responses to Institutional Change, 1957-2007”, European Journal of International Management, 1(3): 225-238.

Whittington, R. 2011, "More SSOP: Commentary on the Special Issue", Business History, 53(1): 169-173.

Whittington, R., and Mayer, M. 2000, The European Corporation. Strategy, Structure, and Social Science. Oxford: Oxford University Press.

Whittington, R., and Mayer, M. 2004, "Economics, Politics and Nations: The Diffusion of the Multidivisional Form in Europe", Journal of Management Studies, 41(7):1057-1082.

Williamson O. 1975, Markets and Hierarchies: Analysis and Antitrust Implications. New York: The Free Press. 
Notes 
1. Chandler, Strategy and Structure; Chandler, Scale and Scope.

2. Kogurt 1992, 'National Organising Principles of Work.'

3. Teece 1993, 'The Dynamics of Industrial Capitalism.'

4. Whittington and Mayer, The European Corporation; Higgins and Toms, 'Explaining corporate success'; Whittington, "More SSOP."

5. Wittington and Mayer, The European Corporation.

6. Iversen and Larsson, 'Strategic transformations.'

7. Rondi, Sleuwagen, and Vannoni, 'Changing industrial and geographical diversification.'

8. De Jong, Sluyterman, and Westerhuis, 'Strategic and structural responses.'

9. Porter, Competitive Strategy; Prahalad and Hamel, 'Core competence.'

10. Iversen and Larsson, 'Strategic transformations.'

11. Wittington and Mayer, The European Corporation.

12. Binda, The Dynamics of Big Business.

13. Whittington and Mayer, 'Economics, politics and nations.'

14. Mayer and Whittington, 'Diversification in context.'

15. Castells, M. 1998. End of Millennium, The Information Age.

16. Porter, Competitive Strategy; Prahalad and Hamel, 'Core competence.'

17. Hall and Soskice, Varieties of Capitalism; Porter, Competitive Advantage of Nations.

18. Fligstein, 'Chandler and the Sociology of Organisations'.

19. Chandler, Scale and Scope.

20. Whittington, 'More SSOP.'

21. Mayer and Wittington, 'Diversification in context', p 1057.

22. Wittington and Mayer, The European Corporation, p 11.

23. For a characterization of Irish economic development based on neoclassical convergence theory, see Honohan and Walsh (2002). Barry (2002) challenges this characterisation and advocates a regional economy explanation of Irish economic development. For a discussion of modernization and dependency theories in the context of Irish economic development, see Kennedy (1989, pp. 50-52). Kennedy acknowledges that "in explaining the spread of modern industry to Ireland, it seems necessary to place particular emphasis on the interaction between local and global conditions" (p.52, italics as per original text); Kennedy, Modern Industrialisation of Ireland, p. 52.

24. See, for example, Bielenberg and Ryan, An Economic History of Ireland, chapter 2.

25. Gross National Product, or Gross Income per head, are more accurate indicators of Irish national income than Gross Domestic Product, as they take account of income earned in Ireland and subsequently repatriated by multinational companies. Data sourced from European Commission (2012) Economic Indicators for Ireland:

http://ec.europa.eu/ireland/economy/economic_indicators_for_ireland/index_en.htm

26. Begley, Delaney and O'Gorman, 'Ireland at the Crossroads: Still a Magnet for Corporate Investment'. For an overview of the establishment of the IDA in 1949, as well as the evolution of the Irish corporation tax regime from the export profits tax relief implemented in 1956, see Barry (2014).

27. Manufacturing enterprises gross output by country of ownership, 2012, available from CSO Census of Industrial Production:

http://www.cso.ie/en/releasesandpublications/er/cip/censusofindustrialproductionenterprises2012/\#.VXcN 8M931IE. For service sector turnover data by country for 2012, see Enterprise Statistics on Distribution and Services:

http://www.cso.ie/px/pxeirestat/Database/eirestat/Enterprise\%20Statistics\%20on\%20Distribution\%20and \%20Services/Enterprise\%20Statistics\%20on\%20Distribution\%20and\%20Services_statbank.asp?SP=Ente rprise $\% 20$ Statistics $\% 20$ on $\% 20$ Distribution $\% 20$ and $\% 20$ Services \&Planguage $=0$

28 Kennedy, Modern Industrialisation of Ireland, p.5; Bielenberg and Ryan, An Economic History of Ireland, p.71. 
29. Barry, Bradley and O’Malley, 'Indigenous and foreign industry'.

30. Lee, Ireland, 1912-1985, p.521.

31. Kennedy, Modern Industrialisation of Ireland, p.25.

32. Ó Gráda, A Rocky Road, p.111.

33. Industrial Policy Review Group (1992); National Economic and Social Council (1982). For a chronology of Irish industrial policy documents, see: O'Gorman and Cooney (2007).

34 OECD 2006, p.23-26; O’Malley, 'The revival of Irish Indigenous Industry', p.35-60; Ó Riain, 'State, Competition and Industrial Change in Ireland', p. 27-53.

35 Ó Riain, 'State, Competition and Industrial Change in Ireland', p.31, 35.

36 Roper, Love and Higon, 'Determinants of export performance', p.589.

37 Forfás, International trade and investment report,p. 25.

38. Enterprise Strategy Group, Ahead of the curve.

39 Forfás, Annual Report, 2012, p.32).

40 CSO, Foreign Direct Investment 2012, Table 7 (p.9); CSO, International Investment Position 19982001, Table 3 (p.7).

41 Barry, Görg, and McDowell, 'Outward FDI and the Investment Development Path', p. 347.

42 CSO, Foreign Direct Investment 2012, Table 7, p.9.

43. In Figure 1 gross value added is defined as output minus intermediate consumption. This equals the sum of employee compensation, gross operating surplus of government and corporations, gross mixed income of unincorporated enterprises and other taxes less other subsidies on production. The shares of each sector are calculated by dividing the value added in each sector by total value added. Total value added is less than GDP because it excludes value-added tax (VAT) and other product taxes. Agriculture consists of agriculture; hunting and forestry; and fishing. Industry consists of mining and quarrying; manufacturing; production and distribution of electricity, gas and water; and construction. Services consists of retail and wholesale trade; transport and communications; real estate, finance, insurance and business services; education, health and other personal services; public administration; and defense.

44. While structure is an important element of Chandler's classification of firms, Williamson (1975) suggested that firms must meet a minimum size threshold before a multi-divisional structure. As the absolute size of Irish firms is relatively small, particularly in the earlier periods, and given the unavailability of data for the period 1978 and 1990, the structure variable was not included in this study.

45. Peneder, 'Intangible investment and human resources'; Peneder, 'Intangible Assets and the Competitiveness of European Industries.'

46. O'Malley, 'Competitive performance in Irish industry.'

47. Wilson et al., 'Mapping corporate Europe.'

48. The sources for the lists as are as follows: Business and Finance 1979, 'Ireland's Top Companies', Vol 16 (18 ${ }^{\text {th }}$ January): 15-25; Business and Finance, 1991, 'The Top Thousand: Ireland's Leadings 1,000 Companies', Vol 27(13) (31 ${ }^{\text {st }}$ January): p 54-117; and Business \& Finance 2012, 'Top 500 Companies in Ireland', Vol. 48(2), (29 ${ }^{\text {th }}$ February):164-175. The 2012 publication reported on firm using 2010 financial data.

49. De Jong, Sluyterman, and Westerhuis, 'Strategic and structural responses'; Iversen \& Larsson, 'Strategic transformations in Danish and Swedish big business.'

50. Iversen and Larsson, 'Strategic transformations in Danish and Swedish big business.'

51. The six were Microsoft Ireland ( $€ 11,346 \mathrm{~m}$.), Dell Products ( $€ 11,201 \mathrm{~m}$.), Covidien ( $€ 10,429 \mathrm{~m}$.), Pfizer Global Supply (€8,056 m.), Google Ireland Ltd. (€7,869 m.), and Bsc International Holdings (€4,817 m.).

52. Görg and Ruane, 'An analysis of backward linkages in the Irish electronics sector.'

53. Faccio and Lang, 'The ultimate ownership of Western European corporations.'

54. Of the fifty firms in 2010 , seven do not publically report any revenue figures. There firms are included in the top fifty firms based on revenue estimates, though they are not included in the estimate of total revenues.

55. All euro amounts are in constant 2010 euros. 
56. Wilson et al., 'Mapping corporate Europe' suggested the use of a $10 \%$ rather than a $5 \%$ concentration threshold.

57. Eurostat indicators on High-tech industry and Knowledge - intensive services (Annex 3 - High-tech aggregation by NACE Rev. 2).

58. As noted above, because the absolute size of Irish firms is relatively small, particularly in the earlier periods, and given the unavailability of data for the period 1978 and 1990, the structure variable was not included in this study.

59 Iversen and Larsson, 'Strategic transformations'; Binda, The Dynamics of Big Business; De Jong, Sluyterman, and Westerhuis, 'Strategic and structural responses.'

60. Faccio and Lang, 'The ultimate ownership of Western European corporations'; Wittington and Mayer, The European Corporation; Colli and Larsson, 'Family business and business history.'

61. Chandler, Strategy and Structure; Wittington and Mayer, The European Corporation.

62. Penrose, Theory of Growth of the Firm.

63. Peters and Waterman, In Search of Excellence; Porter, Competitive Strategy; Prahalad and Hamel, 'Core competency.'

64. Penrose, Theory of Growth of the Firm.

65. Fligstein and Merand, 'Globalization or Europeanization?'; Katzenstein, 'The small European states in the international economy.'

66. Historically, the focus of internationalisation for Irish firms was the UK market, a market that shares a common language, is culturally close, has similar institutional structures, and is geographically close. Exports by Irish owned firms beyond the UK market in the 1970s were low.

67. Binda and Iverson, 'Towards a 'managerial revolution' in European business?'

68. Iversen and Larsson, 'Strategic transformations.'

69. One firm that had very large write-offs is excluded from this analysis.

70. The performance data for 1978 is incomplete. Performance data is available for $38 \%$ of all firms. Data is available for 13 of the 38 firms that were home or partly home market orientated, and 6 of 12 firms that were partly international or international orientated.

71. The tests for differences reported in the tables report statistically significant differences for ownership (Table 1; $\mathrm{p}=0.051$ ) and market orientation (Table $1 ; \mathrm{p}<0.00$ ) and for the interaction between strategic orientation and international orientation (Table 2; $p=0.001$ ) and no significant differences for strategic orientation (Table 1) and for sector (Table 3). Consistent with this, the f-tests included in Appendix 2 report no statistically significant differences for the strategic orientation (diversification) index (Table A2) and a statistically significant difference for the market orientation (internationalisation) index (Table A3).

72. Kogurt 1992, 'National Organising Principles of Work.'

73. Teece 1993, 'The Dynamics of Industrial Capitalism.'

74. Chandler recognised the importance of some aspects of context by highlighting the importance of sector in his study of large firms. For example, he argued that the findings from his research applied to firms in sectors important to the 'second industrial age', sectors he identified as being characterised by capital intensity and scale.

75. See Eurostat for full NACE (Rev 2) classifications: http://epp.eurostat.ec.europa.eu/portal/page/portal/eurostat/home/ Aggregate NACE codes provided in brackets in Table 4.

76. Binda, The Dynamics of Big Business.

77. Bielenberg and Ryan, An Economic History of Ireland, p.12.

78. The Irish Agricultural Organisation Society (later renamed the Irish Co-operative Organisation Society Limited) was established in 1894 by Sir Horace Plunkett, an MP for South County Dublin, as an umbrella organisation for Irish co-operatives (Daly, 2014).

79. Daly, The First Department, p.529-530.

80. Ó Gráda, A Rocky Road, p.111. 
81. Service businesses include firms such as Paddy Power plc, CPL, and Ryanair. Paddy Power plc is a 'multichannel betting and gaming group, that emerged from the merger of three established betting firms in Ireland in 1988 and that has developed an on-line sports betting business; CPL is an international recruitment firm; and Ryanair is an international low cost airline.

82. These thirty one firms include three firms that are corporate spin-offs from other large firms that existed in 1978 or 1990 (Total Produce, OneFiftyOne, and Rosderra Services); two state-owned firms that were privatised (Aer Lingus and Greencore); and a firm created when Irish owners acquired the established Irish operations of a foreign firm who exited the Irish market (Topaz Group)).

83. One of these eleven firms (Glanbia) on the 2010 list resulted from the merger of two large food firms that appeared as separate firms in 1990 and 1978 (Waterfood Co-operative and Avonmore Co-operative); three other firms that were large in 1978 were acquired by firms that appear in the 2010 list of large firms (Golden Vale Co-operative, Odlum Group and William Group).

84. CRH and Smurfit Kappa Group were among the largest firms in each of the three time periods. The evolution of both CRH and Smurfit Kappa Group is associated with a family (the Roche family and the Smurfit family respectively). The firms were public firms listed on the Irish stock exchange in each of 1978, 1990 and 2010. Both of these firms grew large initially by focusing on the Irish market, and then expanding internationally, through a strategy of related diversification, involving the acquisition of firms outside of Ireland.

85. Mayer and Wittington, 'Diversification in context', p 1057.

86. Iversen and Larsson, 'Strategic transformations in Danish and Swedish big business.' 
Table 1: Ownership, strategic orientation and market orientation, Ireland

\begin{tabular}{|l|c|c|c|}
\hline & $\mathbf{1 9 7 8}$ & $\mathbf{1 9 9 0}$ & $\mathbf{2 0 1 0}$ \\
\hline Ownership* & $24(48 \%)$ & $19(38 \%)$ & $22(44 \%)$ \\
Concentrated - family & $14(28 \%)$ & $10(20 \%)$ & $3(6 \%)$ \\
Concentrated - co-operative & $3(6 \%)$ & $5(10 \%)$ & $9(18 \%)$ \\
Concentrated - financial & $2(4 \%)$ & $5(10 \%)$ & $8(16 \%)$ \\
Concentrated - bank & $1(2 \%)$ & $3(6 \%)$ & - \\
Dispersed & $6(12 \%)$ & $8(16 \%)$ & $8(16 \%)$ \\
\hline Strategic orientation** & & & \\
Single & $29(58 \%)$ & $22(44 \%)$ & $24(48 \%)$ \\
Dominant & $2(4 \%)$ & $7(14 \%)$ & $12(24 \%)$ \\
Diversified - related & $14(28 \%)$ & $15(30 \%)$ & $9(18 \%)$ \\
Diversified - unrelated & $5(10 \%)$ & $6(12 \%)$ & $5(10 \%)$ \\
\hline Market orientation*** & & & \\
Home Market orientation & $24(48 \%)$ & $11(22 \%)$ & $7(14 \%)$ \\
Partly Home Market orientation & $14(28 \%)$ & $12(24 \%)$ & $13(26 \%)$ \\
Partly International orientation & $11(22 \%)$ & $24(48 \%)$ & $21(42 \%)$ \\
International orientation & $1(2 \%)$ & $3(6 \%)$ & $9(18 \%)$ \\
\hline
\end{tabular}

* Pearson chi ${ }^{2}$ : 18.231; p-value: 0.051

** Pearson chi ${ }^{2}$ : 9.939; p-value: 0.127

*** Pearson chi ${ }^{2}: 24.404$; p-value: 0.00 
Table 2: International comparisons of ownership, strategic orientation and market orientation

\begin{tabular}{|c|c|c|c|c|c|c|c|c|c|}
\hline & $\begin{array}{c}\text { Ireland } \\
2010 \\
(50)\end{array}$ & $\begin{array}{l}\text { Italy } \\
2002 \\
(50)\end{array}$ & $\begin{array}{c}\text { Netherlands } \\
2003 * * \\
(50)\end{array}$ & $\begin{array}{c}\text { Spain } \\
2002 \\
(50)\end{array}$ & $\begin{array}{c}\text { Ireland } \\
2010 \\
(25) *\end{array}$ & $\begin{array}{c}\text { Denmark } \\
2008 \\
(25)\end{array}$ & $\begin{array}{c}\text { Italy } \\
2002 \\
(25)\end{array}$ & $\begin{array}{c}\text { Spain } \\
2002 \\
(25)\end{array}$ & $\begin{array}{c}\text { Sweden } \\
2008 \\
(25)\end{array}$ \\
\hline \multirow{6}{*}{$\begin{array}{l}\text { Ownership } \\
\text { Concentrated - family (personal) } \\
\text { Concentrated - co-operative (and } \\
\text { foundation) } \\
\text { Concentrated - firm } \\
\text { Concentrated - financial or bank } \\
\text { Dispersed }\end{array}$} & & & & & & & & & \\
\hline & $22(44 \%)$ & $22(44 \%)$ & $\mathrm{n} / \mathrm{a}$ & $10(20 \%)$ & $6(24 \%)$ & $1(4 \%)$ & $12(48 \%)$ & $5(20 \%)$ & $10(40 \%)$ \\
\hline & $3(6 \%)$ & 0 & $\mathrm{n} / \mathrm{a}$ & $3(6 \%)$ & $2(8 \%)$ & $12(48 \%)$ & 0 & $2(8 \%)$ & $1(4 \%)$ \\
\hline & $9(18 \%)$ & $4(8 \%)$ & $\mathrm{n} / \mathrm{a}$ & $2(4 \%)$ & $6(24 \%)$ & $2(8 \%)$ & $1(4 \%)$ & $1(4 \%)$ & \\
\hline & $8(16 \%)$ & 0 & $\mathrm{n} / \mathrm{a}$ & $7(14 \%)$ & $5(20 \%)$ & - & 0 & $7(28 \%)$ & $3(12 \%)$ \\
\hline & $8(16 \%)$ & 0 & $\mathrm{n} / \mathrm{a}$ & $2(4 \%)$ & $6(24 \%)$ & $4(16 \%)$ & 0 & $1(4 \%)$ & $2(8 \%)$ \\
\hline State & $\mathrm{n} / \mathrm{a}$ & $9(18 \%)$ & $\mathrm{n} / \mathrm{a}$ & $4(8 \%)$ & $\mathrm{n} / \mathrm{a}$ & $1(4 \%)$ & $7(28 \%)$ & 0 & $3(12 \%)$ \\
\hline Foreign & $\mathrm{n} / \mathrm{a}$ & $15(30 \%)$ & $\mathrm{n} / \mathrm{a}$ & $22(44 \%)$ & $\mathrm{n} / \mathrm{a}$ & $5(20 \%)$ & $5(20 \%)$ & $9(36 \%)$ & $6(24 \%)$ \\
\hline \multicolumn{10}{|l|}{ Strategy } \\
\hline Single & $24(48 \%)$ & $9(18 \%)$ & $(8 \%)$ & $11(22 \%)$ & $10(40 \%)$ & $16(64 \%)$ & $3(12 \%)$ & $4(16 \%)$ & $8(32 \%)$ \\
\hline Dominant & $12(24 \%)$ & $11(22 \%)$ & $(13 \%)$ & $10(20 \%)$ & $9(36 \%)$ & $5(20 \%)$ & $3(12 \%)$ & $5(20 \%)$ & $5(20 \%)$ \\
\hline Diversified - related & $9(18 \%)$ & $20(40 \%)$ & $(71 \%)$ & $25(50 \%)$ & $4(16 \%)$ & $3(12 \%)$ & $11(44 \%)$ & $\begin{array}{c}13 \\
(52 \%)\end{array}$ & $8(32 \%)$ \\
\hline Diversified - unrelated & $5(10 \%)$ & $10(20 \%)$ & $(8 \%)$ & $4(8 \%)$ & $2(8 \%)$ & $1(4 \%)$ & $8(32 \%)$ & $3(12 \%)$ & $4(16 \%)$ \\
\hline \multicolumn{10}{|l|}{ Market orientation } \\
\hline Home Market orientation & $7(14 \%)$ & $24(48 \%)$ & $(4 \%)$ & $16(32 \%)$ & $1(4 \%)$ & $5(20 \%)$ & $11(44 \%)$ & $6(24 \%)$ & $2(8 \%)$ \\
\hline Partly Home Market orientation & $13(26 \%)$ & $11(22 \%)$ & $(25 \%)$ & $19(38 \%)$ & $4(16 \%)$ & $2(8 \%)$ & $8(32 \%)$ & $\begin{array}{c}11 \\
(44 \%)\end{array}$ & $3(12 \%)$ \\
\hline Partly International orientation & $21(42 \%)$ & $14(28 \%)$ & $(31 \%)$ & $15(30 \%)$ & $11(44 \%)$ & $5(20 \%)$ & $5(20 \%)$ & $8(32 \%)$ & $8(32 \%)$ \\
\hline International orientation & $9(18 \%)$ & $1(2 \%)$ & $(40 \%)$ & 0 & $9(36 \%)$ & $13(52 \%)$ & $1(4 \%)$ & 0 & $12(48 \%)$ \\
\hline
\end{tabular}

*Does not include unlimited Irish firms.

** Only reported percentages. Dataset is only public firms in manufacturing and services sectors. 
Table 3: Patterns of strategy and internationalisation, Ireland

\begin{tabular}{|l|c|c|c|c|c|c|}
\hline \multirow{4}{*}{ Strategic Orientation: } & \multicolumn{2}{|c|}{1978} & \multicolumn{2}{c|}{1990} & \multicolumn{2}{c|}{2010} \\
\cline { 2 - 7 } & \multicolumn{2}{|c|}{ Market Orientation } & \multicolumn{2}{c|}{ Market Orientation } & \multicolumn{2}{c|}{ Market Orientation } \\
\cline { 2 - 7 } & $\begin{array}{l}\text { Home/ } \\
\text { Partly Home }\end{array}$ & $\begin{array}{l}\text { Partly Int./ } \\
\text { International }\end{array}$ & $\begin{array}{l}\text { Home/ } \\
\text { Partly Home }\end{array}$ & $\begin{array}{l}\text { Partly Int./ } \\
\text { International }\end{array}$ & $\begin{array}{l}\text { Home/ } \\
\text { Partly Home }\end{array}$ & $\begin{array}{l}\text { Partly Int./ } \\
\text { International }\end{array}$ \\
\cline { 2 - 7 } Single/ Dominant & $26(52 \%)$ & $5(10 \%)$ & $18(36 \%)$ & $11(22 \%)$ & $16(32 \%)$ & $20(40 \%)$ \\
Diversified- & $12(24 \%)$ & $7(14 \%)$ & $5(10 \%)$ & $16(32 \%)$ & $4(8 \%)$ & $10(20 \%)$ \\
\hline
\end{tabular}

Pearson chi $^{2}: 21.547$; p-value: 0.001 
Table 4: Fifty largest firms by sector, Ireland

\begin{tabular}{|c|c|c|c|c|c|c|c|c|c|}
\hline \multirow[t]{2}{*}{ Sector } & \multicolumn{3}{|c|}{ Number of Firms (\%) } & \multicolumn{3}{|c|}{$\begin{array}{c}\text { Revenues } \\
(€ \text { million, 2010) }\end{array}$} & \multicolumn{3}{|c|}{$\begin{array}{c}\text { Revenues } \\
(\%)\end{array}$} \\
\hline & 1978 & 1990 & 2010 & 1978 & 1990 & $2010^{41}$ & 1978 & 1990 & 2010 \\
\hline $\begin{array}{l}\text { Agriculture, forestry and fishing (A) and Mining } \\
\text { and quarrying (B) }\end{array}$ & - & $1(2 \%)$ & $3(6 \%)$ & - & 301 & 1,919 & - & $1 \%$ & $3 \%$ \\
\hline Manufacture of food products, beverages (C) & $19(38 \%)$ & $17(34 \%)$ & $9(18 \%)$ & 4,389 & 9,884 & 9,262 & $40 \%$ & $37 \%$ & $13 \%$ \\
\hline $\begin{array}{l}\text { Manufacture of textiles, etc. and of wood, paper } \\
\text { products (C) }\end{array}$ & $4(8 \%)$ & $2(4 \%)$ & $3(6 \%)$ & 1,167 & 3,438 & 7,870 & $11 \%$ & $13 \%$ & $11 \%$ \\
\hline $\begin{array}{l}\text { Manufacture of chemicals, pharma, plastics, } \\
\text { metals, electrical, transport (C) }\end{array}$ & $3(6 \%)$ & $6(12 \%)$ & $4(8 \%)$ & 1,040 & 3,962 & 20,655 & $9 \%$ & $15 \%$ & $29 \%$ \\
\hline Utilities (D and E) & - & - & $2(4 \%)$ & - & - & 620 & - & - & $1 \%$ \\
\hline Construction (F) & $4(8 \%)$ & $3(6 \%)$ & $3(6 \%)$ & 546 & 890 & 1,318 & $5 \%$ & $3 \%$ & $2 \%$ \\
\hline Wholesale and retail $(\mathrm{G})$ & $18(36 \%)$ & $20(40 \%)$ & $18(36 \%)$ & 3,586 & 8,211 & 22,660 & $32 \%$ & $30 \%$ & $32 \%$ \\
\hline Transport (H) & $1(2 \%)$ & - & $3(6 \%)$ & 124 & - & 3,802 & $1 \%$ & - & $5 \%$ \\
\hline Publishing, arts, entertainment (J) & - & $1(2 \%)$ & $2(4 \%)$ & - & 294 & 1,070 & - & $1 \%$ & $2 \%$ \\
\hline Services $(\mathrm{L}, \mathrm{M}, \mathrm{N})$ & $1(2 \%)$ & - & $3(6 \%)$ & 201 & - & 1,069 & $2 \%$ & - & $2 \%$ \\
\hline Total & $50(100 \%)$ & $50(100 \%)$ & $50(100 \%)$ & 11,053 & 26,980 & 70,245 & $100 \%$ & $100 \%$ & $100 \%$ \\
\hline
\end{tabular}

Pearson chi $^{2}$ : 20.267; p-value: 0.318 (Number of firms) 
Table 5: Fifty largest firms by technology and knowledge intensity, Ireland

\begin{tabular}{|c|c|c|c|c|c|c|}
\hline \multirow[t]{2}{*}{ Sector } & \multicolumn{3}{|c|}{ Number of Firms } & \multicolumn{3}{|c|}{$\%$} \\
\hline & 1978 & 1990 & 2010 & 1978 & 1990 & 2010 \\
\hline \multicolumn{7}{|l|}{ Manufacturing sectors } \\
\hline - High-technology & - & - & 1 & - & - & $2 \%$ \\
\hline - Medium-high-technology & 1 & 3 & 1 & $2 \%$ & $6 \%$ & $2 \%$ \\
\hline - Medium-low-technology & 2 & 3 & 2 & $4 \%$ & $6 \%$ & $4 \%$ \\
\hline - Low-technology & 23 & 19 & 12 & $46 \%$ & $38 \%$ & $24 \%$ \\
\hline \multicolumn{7}{|l|}{ Knowledge-intensive services (KIS) } \\
\hline - Knowledge-intensive market services & 1 & - & 5 & $2 \%$ & - & $10 \%$ \\
\hline - High-tech knowledge-intensive services & - & - & 1 & - & - & $2 \%$ \\
\hline - Knowledge-intensive financial services & 1 & - & - & $2 \%$ & - & - \\
\hline - Other knowledge-intensive services & - & 1 & 2 & - & $2 \%$ & $4 \%$ \\
\hline Less knowledge-intensive services (LKIS) & & & & & & \\
\hline - Less knowledge-intensive market services & 18 & 20 & 20 & $36 \%$ & $40 \%$ & $40 \%$ \\
\hline - Other less knowledge-intensive services & - & - & - & - & - & - \\
\hline Other sectors (including construction, utilities) & 4 & 4 & 6 & $8 \%$ & $8 \%$ & $12 \%$ \\
\hline Total & 50 & 50 & 50 & $100 \%$ & $100 \%$ & $100 \%$ \\
\hline
\end{tabular}


Table 6: Manufacturing firms by Peneder's classification, Ireland

\begin{tabular}{|c|c|c|c|c|c|c|}
\hline \multirow[t]{2}{*}{ Sector } & \multicolumn{3}{|c|}{ Number of Firms } & \multicolumn{3}{|c|}{$\%$} \\
\hline & $\begin{array}{c}1978 \\
(n=29)\end{array}$ & $\begin{array}{c}1990 \\
(n=28)\end{array}$ & $\begin{array}{c}2010 \\
(n=19)\end{array}$ & 1978 & 1990 & 2010 \\
\hline Industry type & & & & & & \\
\hline - $\quad$ Mainstream manufacturing (MM) & 4 & 5 & 5 & $14 \%$ & $18 \%$ & $26 \%$ \\
\hline - Labour intensive industries (LI) & 5 & 5 & 4 & $17 \%$ & $18 \%$ & $21 \%$ \\
\hline - Capital intensive industries (CI) & 1 & - & - & $3 \%$ & - & - \\
\hline - Marketing driven industries (MDI) & 19 & 18 & 9 & $66 \%$ & $64 \%$ & $48 \%$ \\
\hline - Technology driven industries (TDI) & - & - & 1 & - & - & $5 \%$ \\
\hline Skill type & & & & & & \\
\hline - High & - & 1 & 1 & - & $3 \%$ & $5 \%$ \\
\hline - Medium - White collar & 2 & 3 & 3 & $7 \%$ & $11 \%$ & $16 \%$ \\
\hline - Medium - Blue collar & 4 & 5 & 5 & $14 \%$ & $18 \%$ & $26 \%$ \\
\hline - Low & 23 & 19 & 10 & $79 \%$ & $68 \%$ & $53 \%$ \\
\hline
\end{tabular}


Figure 1: Value added by activity, as a percentage of total value added, 1970-2010

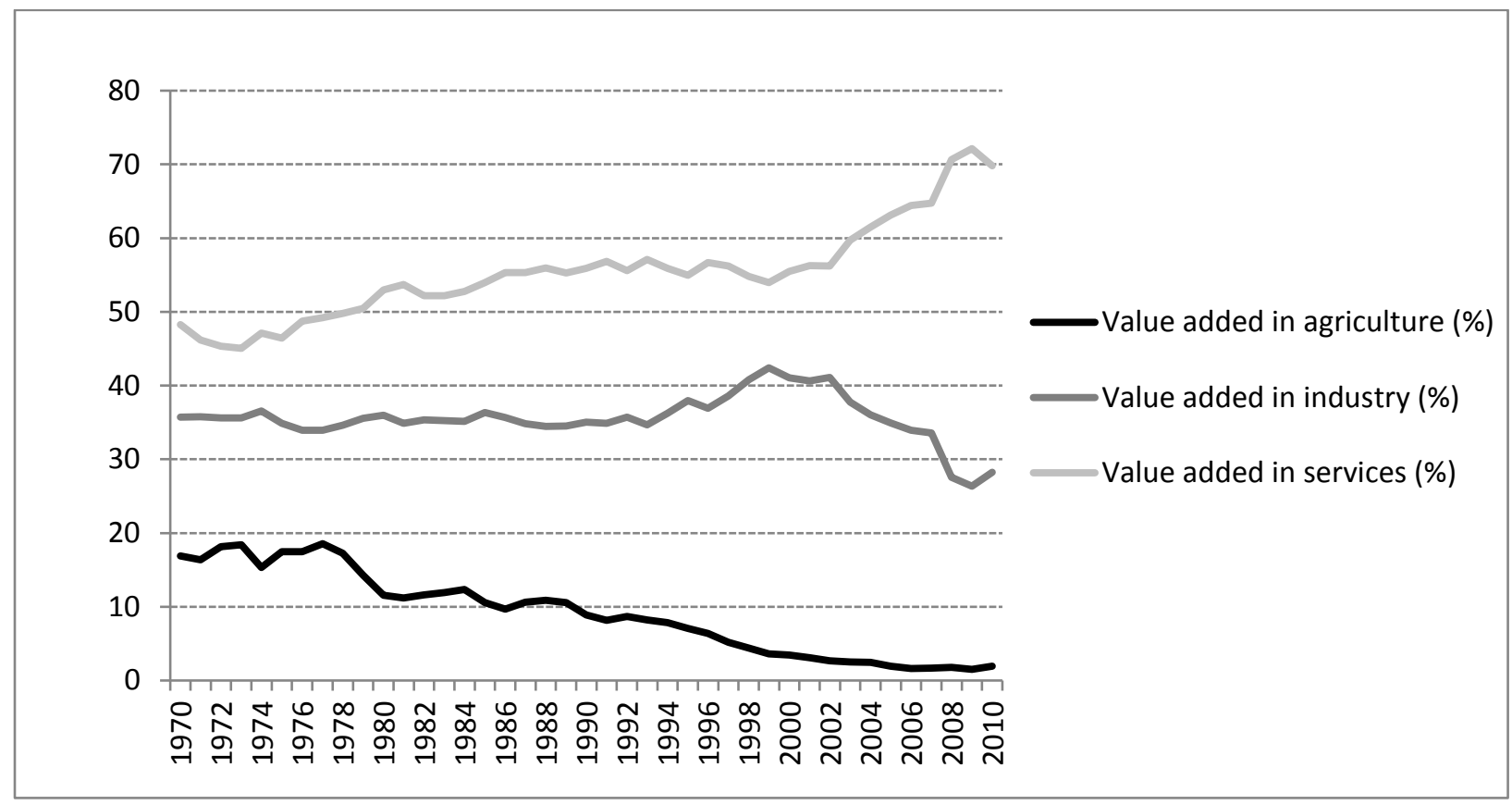

Source: OECD STAN database for 1970-2007 data; www.cso.ie for 2007-2010 values. 19701993 OECD STAN data are estimated values.

http://www.cso.ie/en/media/csoie/releasespublications/documents/economy/2010/nie_2010.pdf 


\section{Appendix 1: Ireland's largest firms}

Table A1: Listing of firms, 1978, 1990, 2010*

\begin{tabular}{|c|c|c|}
\hline 1978 & 1990 & 2010 \\
\hline Abbey Ltd $(\mathrm{F})^{* *}$ & Agra Trading $(\mathrm{G})$ & ADM Londis plc $(\mathrm{G})$ \\
\hline Arnotts $(\mathrm{G})$ & Allied Distributive Merchants (G) & Aer Lingus Group plc $(\mathrm{H})$ \\
\hline Avenue Investments (L) & Avonmore Foods plc (CA) & Ardagh Glass Sales Ltd (C) \\
\hline Avonmore (Co-operative) (CA) & BWG Foods $(\mathrm{G})$ & Arlesse $(\mathrm{CA})$ \\
\hline Ballyclough (Co-operative) (CA) & Cahill May Roberts Group plc (G) & Arrow Group Ltd (CA) \\
\hline Brooks Watson $(\mathrm{G})$ & Classic Meats (CA) & Ballinasmalla Holding Ltd $(\mathrm{G})$ \\
\hline Castlemahon (Co-operative) (CA) & Clondalkin Group (C) & C \& C Group plc (CA) \\
\hline Cement Roadstone $(\mathrm{C})$ & Cork Co-Operative Marts (G) & Clondalkin Group (C) • \\
\hline Clery \& Co. (1941) $(\mathrm{G})$ & $\mathrm{CRH}(\mathrm{C})$ & Cpl Resources plc $(\mathrm{N})$ \\
\hline Clondalkin Mills (C) & Dairygold Co-Op Society (CA) & $\mathrm{CRH}(\mathrm{C})$ \\
\hline Clover Meats (Co-operative) (CA) & Dunnes Stores $(\mathrm{G})$ & DCC plc $(G)$ \\
\hline Cork Marts (Co-operative) $(\mathrm{G})$ & Fitzwilton $(\mathrm{G})$ & Dragon Oil plc $(\mathrm{B})$ \\
\hline Denis Coakley $(\mathrm{G})$ & Food Industries plc (G) & Dunnes Stores $(\mathrm{G})$ \\
\hline Dunnes Stores $(\mathrm{G})$ & Fyffes $(\mathrm{G})$ & Eason \& Son Ltd $(\mathrm{G})$ \\
\hline George Bell Group $(\mathrm{H})$ & Gallagher Dublin (CA) & Elan Pharma International Ltd (C) \\
\hline Golden Vale (Co-operative) (CA) & Glen Dimplex $(\mathrm{C})$ & Elliott Holdings Ltd $(\mathrm{F})$ \\
\hline Golden Vale Marts (Co-operative) (G) & Golden Vale (CA) & Fyffes plc $(\mathrm{G})$ \\
\hline Goodman Group (CA) & Golden Vale Marts (G) & Glanbia plc (CA) \\
\hline Gowan Group $(\mathrm{G})$ & Goodman International (CA) & Glen Dimplex $(\mathrm{C})$ \\
\hline H. Williams (G) & IAWS Group (CA) & Grafton Group plc $(\mathrm{G})$ \\
\hline IAWS (Co-operative) (CA) & Independent Newspapers $(\mathrm{J})$ & Greencore Group plc (CA) \\
\hline Irish Distillers $(\mathrm{CA})$ & Irish Distillers Group (CA) & Icon plc $(\mathrm{M})$ \\
\hline Irish Leathers $(\mathrm{C})$ & IWP International (C) & Independent News \& Media plc (J) \\
\hline J. Smurfit (C) & James Crean plc (CA) & Inver Energy Ltd $(\mathrm{G})$ \\
\hline J S Lister $(\mathrm{G})$ & Jefferson Smurfit Group (C) & Irish BWG $(\mathrm{G})$ \\
\hline Jacobs (CA) & John Sisk \& Son $(\mathrm{F})$ & Irish Continental Group plc (H) \\
\hline John Sisk \& Son (F) & Jones Group (C) & James A. Barry \& Company (G) \\
\hline Kerry (Co-operative) (CA) & Kepak (CA) & Kepak (CA) \\
\hline Killeshandra (Co-operative) (CA) & Kerry Group (CA) & Kerry Group plc (CA) \\
\hline McDonagh Group (F) & Lakeland Dairies (CA) & Kingspan Group plc (C) \\
\hline McInerney $(\mathrm{F})$ & Liffey Meats (CA) & M\&J Gleeson (Investment) (CA) \\
\hline McMullan Bros. (G) & Mace Marketing Services (Ireland) (G) & Musgrave Group ple $(\mathrm{G})$ \\
\hline Mitchelstown (Co-operative) (CA) & Masstock (A) & NTR plc (D) \\
\hline Musgraves (G) & Maxol Group $(\mathrm{G})$ & O' Flaherty Holdings Ltd (G) \\
\hline North Connacht Farmers (Co-op) (CA) & McInerney Properties (F) & One Fifty One plc (E) \\
\hline $\mathrm{O}^{\prime}$ Flaherty $(\mathrm{G})$ & MF Kent Group (F) & Origin Enterprises plc (A) \\
\hline Odlum Group (CA) & Musgrave (including SuperValue) (G) & Paddy Power plc (R) \\
\hline PJ Carroll (CA) & National Wholesale $(\mathrm{G})$ & Project Management Holdings (M) \\
\hline Premier Hughes (CA) & North Connacht Farmers Co-op (CA) & Rosderra Services (CA) \\
\hline $\mathrm{R} \& \mathrm{H}$ Hall $(\mathrm{CA})$ & $\mathrm{O}^{\prime}$ Flaherty Holdings $(\mathrm{G})$ & Ryanair Holdings plc $(\mathrm{H})$ \\
\hline Reg. Armstrong Holdings (C) & PJ Carroll and Company (CA) & Siac Holdings Ltd $(\mathrm{F})$ \\
\hline Roches Stores $(\mathrm{G})$ & Purcell Exports $(\mathrm{G})$ & Sicon Limited $(\mathrm{F})$ \\
\hline Superquinn $(\mathrm{G})$ & R\&H Hall $(\mathrm{G})$ & Smurfit Kappa Group plc (C) \\
\hline Tedcastle Group (G) & Sugar Distributors Holdings (G) & Stafford Holdings Ltd $(\mathrm{G})$ \\
\hline Tunney Group (CA) & Superquinn $(\mathrm{G})$ & Tedcastle Holdings $(\mathrm{G})$ \\
\hline Waterford (Co-operative) (CA) & Tedcastle McCormick $(\mathrm{G})$ & Topac Energy Group Ltd (G) \\
\hline Waterford Glass (C) & Unidare plc $(\mathrm{C})$ & Total Produce plc $(\mathrm{G})$ \\
\hline Wexford Marts (Co-operative) (G) & United Food Corporation Group (CA) & Uniphar plc $(\mathrm{G})$ \\
\hline Williams Group $(\mathrm{G})$ & Waterford Foods (CA) & United Drug plc $(\mathrm{G})$ \\
\hline Youghal Carpets (C) & Waterford Wedgewood Group (C) & William P. Keelings \& Son • (A) \\
\hline
\end{tabular}


* Firm names are as per the original published lists.

** Sector classification: (A) Agriculture, forestry and fishing; (B) Mining and quarrying; (C) Manufacturing (including textiles, wood, paper products, pharmaceuticals, plastics, metals, electrical, transport); (CA) Manufacturing (food products, beverages); (D) Utilities; (F)

Construction; (G) Wholesale and retail; (H) Transport (including airlines); (J) Information and communication; (L) Real estate; (M) Professional, scientific and technical; (N) Administrative and support service; and (R) Arts, entertainment and recreation.

- These (privately held) firms are added to the 2010 listing based on estimated revenues. As noted earlier, in 2010 Irish firms could elect for a legal form of ownership that did not require public disclosure of accounts. 


\section{Appendix 2: Test of statistical significance}

We replicate the approach of Iversen and Larsson to test the statistical significance of the data. ${ }^{86}$ Iversen and Larsson computed 'simple weighted average' indices, one for diversification and one for internationalisation. The approach is replicated in the tables below.

The indices and tests

The diversification index characterises the strategic orientation of the largest fifty Irish firms in each of 1978, 1990 and 2010. The weighted average is calculated by assigning a value of 1 to 'single', 2 to 'dominant', 3 to 'related diversification' and 4 to 'unrelated diversification'. Therefore a low index figure indicates a focus on the core business and a higher index figure suggests greater levels of diversification. The internationalisation largest index characterises the 'market orientation' of the fifty Irish firms. The weighted average is calculated by assigning a value of 1 to 'home market', 2 to 'partly home market', 3 to 'partly international, and 4 'international'. Therefore a higher index value indicates higher levels of internationalisation.

Iversen and Larsson used the f-test to test for differences across the time periods. Assuming a null hypothesis that there is no change overtime, the f-test provides a test of changes in the two indices. The f-test is a measure of between group differences rather than a measure of within group difference. As Iversen and Larsson (2011) highlight, this test will have poor results if the indices change gradually (i.e. were change is incremental and where the standard deviations for the years (groups) are similar and large).

\section{Diversification (strategic orientation) index}

The diversification index is 1.90, 2.10, and 1.90 in 1978, 1990 and 2010 respectively (Table A2). The f-test finds that there is no statistically significant difference across the three time periods.

Table A2: F-test - Strategic orientation (diversification) index

\begin{tabular}{|ccccc|cc|}
\hline Year & $\begin{array}{c}\text { Single } \\
(=\mathbf{1})\end{array}$ & $\begin{array}{c}\text { Dominant } \\
(\mathbf{= 2})\end{array}$ & $\begin{array}{c}\text { Diversified- } \\
\text { related (=3) }\end{array}$ & $\begin{array}{c}\text { Diversified- } \\
\text { unrelated (=4) }\end{array}$ & $\begin{array}{c}\text { Div. } \\
\text { index }\end{array}$ & S \\
\hline 1978 & 29 & 2 & 14 & 5 & 1.90 & 1.13 \\
1990 & 22 & 7 & 15 & 6 & 2.10 & 1.11 \\
2010 & 24 & 12 & 9 & 5 & 1.90 & 1.04 \\
\hline
\end{tabular}

With-group variance estimate: 1.19

Between-group variance estimate: 0.65

F $(2,147): 0.55$

P-value: 0.58 
Internationalisation (market orientation) index

The internationalisation index is 1.78, 2.38, and 2.64 in 1978, 1990 and 2010 respectively (Table A3). The f-test finds that there is a statistically significant difference across the three time periods $(\mathrm{p}<0.00)$.

Table A3: F-test - Market orientation (internationalisation) index

\begin{tabular}{|ccccc|cc|}
\hline Year & $\begin{array}{c}\text { Home } \\
(\mathbf{= 1})\end{array}$ & $\begin{array}{c}\text { Partly } \\
\text { Home } \\
(=2)\end{array}$ & $\begin{array}{c}\text { Partly } \\
\text { International } \\
(=3)\end{array}$ & $\begin{array}{c}\text { International } \\
(=\mathbf{= 4})\end{array}$ & $\begin{array}{c}\text { Int. } \\
\text { index }\end{array}$ & S \\
\hline 1978 & 24 & 14 & 11 & 1 & 1.78 & 0.86 \\
1990 & 11 & 12 & 24 & 3 & 2.38 & 0.90 \\
2010 & 7 & 13 & 21 & 9 & 2.64 & 0.94 \\
\hline
\end{tabular}

With-group variance estimate: 0.82

Between-group variance estimate: 9.53

F $(2,147): 11.69$

P-value: 0.00 